\title{
Export Product Diversification, Poverty and Tax Revenue in Developing Countries
}

\author{
Sèna Kimm GNANGNON ${ }^{1}$
}

Manuscript date: September 2020

\begin{abstract}
The current paper has examined the effect of both export product diversification and poverty on non-resource tax revenue in developing countries. The analysis has used an unbalanced panel dataset of 111 countries over the period 1980-2014. Based on the Blundell and Bond twostep system Generalized Methods of Moments technique, the empirical analysis has shown interesting findings. Export product concentration and poverty influence negatively non-resource tax revenue over the full sample, but this effect varies across countries in the sample. Furthermore, the effect of export product diversification on non-resource tax revenue performance depends on the level of poverty. It appears that export product diversification influences positively nonresource tax revenue performance in countries that experience lower poverty rates. From a policy perspective, these findings show that policies in favour of diversifying export product baskets and reducing poverty would contribute to enhancing non-resource tax revenue performance in developing countries.
\end{abstract}

Keywords: Export Product diversification; Poverty; Non-resource tax revenue.

JEL Classification: F10; I32; H20.

\section{DISCLAIMER}

This is a working paper, which represents the personal opinions of individual staff members and is not meant to represent the position or opinions of the WTO or its Members, nor the official position of any staff members. Any errors or omissions are the fault of the author. The author declares no competing interests.

\footnotetext{
${ }^{1}$ World Trade Organization (W'TO), CH-1211 Geneva, Switzerland.

E-mail for correspondence: kgnangnon@yahoo.fr
} 


\section{Introduction}

Developing countries need huge amounts of financial resources to finance their development objectives. Public revenue mobilization remains the first and foremost means to ensure a stream of financial resources for governments, including in developing countries. A voluminous literature ${ }^{2}$ has been devoted to the determinants of public revenue (including tax revenue), notably in developing countries. However, to the best of our knowledge, the relationship between export product diversification and public revenue, on the one hand, and poverty and public revenue, on the other hand, has received scant attention in this literature. To our knowledge, only Gnangnon (2018) and Gnangnon and Brun (2017) have explored the effect of export product diversification on public revenue performance in developing. This issue is all the more relevant that the literature has now well established that to ensure a sustainable economic growth and development path, developing countries would need to diversify their export product baskets away from primary commodities, towards higher value-added products, including manufacturing products (e.g., Hausman et al. 2007; Herzer and Nowak-Lehmann, 2006; Naudé et al. 2010; Redding, 1999; Prebisch, 1950; Singer, 1950). In fact, export product diversification can contribute to enhancing economic growth (e.g., Aditya and Acharyya, 2013; Can and Gozgor, 2017; Hausmann et al. 2007; Herzer and Nowak-Lehmann, 2006; Mania and Rieber, 2019; Naudé et al. 2010; Redding, 1999), reducing aggregate output volatility (e.g., di Giovanni et al., 2014; Haddad et al. 2013; Malik and Temple, 2009; Camanho da Costa Neto and Romeu, 2011) as well as firms' output volatility (e.g., Kramarz et al. 2020; Vannoorenberghe et al. 2016), dampening export revenue volatility (e.g., Athukorola, 2000; Prebisch, 1950; Singer, 1950; Stanley and Bunnag, 2001), and reducing poverty (e.g., Pugliese et al., 2017; Santos-Paulino, 2017; Weinberger and Lumpkin, 2007).

Poverty reduction (at least in monetary terms) is also at the heart of the policymakers' agenda both at the national and international levels. For example, in September 2015, the United Nations Members adopted seventeen Sustainable Development Goals ${ }^{3}$ (SDGs) (which have replaced the

2 A recent literature review on the matter has recently been provided by Prichard (2016). Recent studies include for example, Abdelwahed (2020); Baunsgaard and Keen (2010); Bird et al. (2008); Brun et al. (2015); Cagé and Gadenne (2018); Crivelli (2016); Crivelli and Gupta (2014, 2018); Gnangnon (2018, 2019a); Gnangnon and Brun (2017, 2018, 2019); Langer and Korzhenevych (2019); Morrissey et al. (2016); and Oz-Yalaman (2019).

${ }^{3}$ The 17 SDGs were adopted by the General Assembly of the United Nations, and contained in the document "Transforming our world: the 2030 Agenda for Sustainable Development", whose reference number is A/RES/70/1. The SDGs replaced the Millennium Development Goals (MDGs) (adopted in September 2000 by United Nations Members), the first of these goals being to halve extreme poverty by the target date of 2015 . 
Millennium Developed Goals ${ }^{4}$ ). The first of the SDGs concerns poverty reduction, and specifically aims at ending poverty in all its forms everywhere (see page 14 of the United Nations document A/RES/70/1). While the macroeconomic effects of export product diversification have received a large attention from scholars and researchers (see studies cited above), the macroeconomic effects of poverty have been less explored. For example, the extent of the related literature has focused on the effect of poverty on human capital (e.g., Bain et al. 2013; Hanson et al. 2013; Haushofer and Fehr, 2014; Lichand et al., 2020), labour productivity (e.g., Hill and Sandfort, 1995), economic growth (e.g., López, 2006; Ravallion, 2012, 2016), economic development (e.g., Nakabashi, 2018), export product diversification (e.g., Gnangnon, 2019b) and trade openness (e.g., Gnangnon, 2019c). To the best of our knowledge, there is no published work on the effect of poverty on public revenue, including tax revenue.

The present analysis investigates the effect of export product diversification and poverty on tax revenue performance (measured by the tax revenue share in gross domestic product) in developing countries. Additionally, it examines how export product diversification interacts with poverty in influencing tax revenue performance in developing countries.

The analysis is conducted using an unbalanced panel dataset of 111 countries, over the period 1980-2014, and the Blundell and Bond two-step system Generalized Methods of Moments technique. Results have shown that over the full sample, export product concentration and poverty lead to lower non-resource tax revenue performance. However, this effect varies across countries in the sample. Additionally, export product diversification influences positively non-resource tax revenue performance in countries that experience lower poverty rates.

The remainder of the paper is structured around five Sections. Section 2 discusses theoretically how both export product diversification and poverty can affect tax revenue, and in particular how both factors interact in influencing developing countries' tax revenue performance. Section 3 presents the model specification used to address empirically the issue at the heart of the analysis. Section 4 presents the estimation approach, and Section 5 discusses empirical outcomes. Section 6 concludes.

\section{Export product diversification, poverty and tax revenue}

Gnangnon and Brun (2017) have shown that export product upgrading (including both export product diversification and export product quality) influences positively non-resource tax

${ }^{4}$ It is worth noting that the MDGs were adopted at the Millennium Summit of the United Nations held at the United Nations headquarters in New York, on 8 September 2000. The first MDG aimed at to halving extreme poverty by the target date of 2015 . 
revenue performance. The effect of export product upgrading on public revenue can translate through several avenues (see also Gnangnon, 2020). First, export product upgrading generates higher income for traders, including trading firms, and employees in these firms. For example, export product diversification can influence export performance at the aggregate level (e.g., Camanho and Romeu, 2011; del Rosal, 2019; Funke and Ruhwedel, 2001, 2002) and increase their income. According to Camanho and Romeu (2011), product diversification has helped to enhance export resilience in Latin American countries during the global financial crisis, including by dampening the trade collapse effect of the 2018 global financial crisis. However, this was not the case for geographical diversification. Funke and Ruhwedel $(2001,2002)$ have reported for 10 East Asian countries and 15 Organization for Economic Co-operation and Development (OECD) countries that export product variety enhances export performance. del Rosal (2019) has obtained for Spain that export product concentration induces greater export performance by destination country of Spain exports. At the firm-level, export product diversification also influences positively export performance (e.g., Balabanis, 2001; Njikam, 2017; Solano et al. 2019; Xuefeng and Yaşar, 2016). Some few studies have shown that export product diversification may induce higher employment, i.e., a higher demand for labour. Naude and Rossouw (2011) have used data for Brazil, China, India and South Africa over the period 1962-2000, and obtained that export product diversification has led to higher employment in South Africa. However, for the other countries, it is rather export concentration that influences positively employment. They have concluded that export product diversification induces higher employment only at the early stages of development. Songwe and Winkler (2012) have shown for 30 African countries over the period 1995-2008 that export product diversification has not resulted in higher labor demand. However, these findings might not apply to all developing countries. UNCTAD (2018) has used a large sample of both advanced and developing countries to conclude that export product diversification promotes employment in developing countries and advanced countries alike, although this positive effect is lesser in African countries than in other countries.

The rise in trading firms' income (due to greater export product diversification) can lead firms to increase their demand for skilled and unskilled workers. For governments, these would result in higher corporate income tax revenue, as well as higher personal income tax revenue, and hence in higher direct tax revenue. At the same time, the afore-mentioned positive effects of export product upgrading on the income of trading firms and their employees could also translate into higher domestic consumption, which would generate higher indirect tax revenue, including value added tax (VAT) revenue and excise tax revenue. If the income rise results in higher imports, the government could collect higher international trade tax revenue. Taking all these together, the 
positive effect of export product diversification on corporate (trading firms)'s income and the income of employees could induce higher direct tax revenue, indirect tax revenue, as well as international trade tax revenue, and ultimately result in higher total tax revenue.

In addition to its tax revenue effect through employees and firms' income, export product diversification can also affect tax revenue through its effect on output volatility. On the one hand, by stabilizing firms' output volatility or export revenue volatility (e.g., Kramarz et al. 2020; Vannoorenberghe et al. 2016), export product diversification can help increase tax revenue through the channels described above. On the other hand, export product diversification can contribute to reducing aggregate output volatility (e.g., di Giovanni et al., 2014; Haddad et al. 2013; Lee and Zhang, 2019; Malik and Temple, 2009; Camanho da Costa Neto and Romeu, 2011). At the same time, macroeconomic volatility, including output volatility often induces lower economic growth and adversely affects welfare (e.g., Acemoglu et al. 2003; Alimi, 2016; Antonakakis and Badinger, 2016; Badinger, 2010; Berument et al. 2012; Campi and Dueñas, 2020; Fata, 2002; Hnatkovska and Loayza, 2005; Ramey and Ramey, 1995). In turn, economic growth contributes significantly to determining the breath of the tax base, and hence tax revenue performance (e.g., Besley and Persson, 2014; Tosun and Abizadeh, 2007). Against this backdrop, we expect that greater export product concentration would be associated with lower tax revenue performance in countries that experience higher economic growth volatility. Likewise, in light of the positive effect of export product diversification on economic growth (e.g., Aditya and Acharyya, 2013; Can and Gozgor, 2017; Hausmann et al. 2007; Herzer and Nowak-Lehmann, 2006; Mania and Rieber, 2019; Naudé et al. 2010; Redding, 1999), one could also expect that the effect of export product diversification on tax revenue performance may translate through the economic growth channel: export product diversification can improve tax revenue performance in countries that experience a higher economic growth.

As for the effect of poverty on tax revenue, we expect a rise in the poverty level to result in lower tax revenue performance. Higher poverty levels reflect the lack of resources to meet the minimum basic necessities of life. As a result, a rise in poverty rates leads to lower consumption (e.g., Blocker et al., 2013; Chakravarti, 2006; Ravallion, 2012), lower investment - for example - in human capital (e.g., Bain et al. 2013; Hanson et al. 2013; Haushofer and Fehr, 2014; Lichand et al., 2020), lower productivity (e.g., Breunig and Majeed, 2020; Hill and Sandfort, 1995), lower economic growth (e.g., López, 2006; Ravallion, 2012, 2016), and lower economic development (e.g., Nakabashi, 2018). The decline in consumption due to the rise in poverty rates would result in lower indirect tax revenue, including through lower VAT and excises tax revenue, and eventually import tariff revenue (if the poverty-related fall in consumption translates into lower imports). 
Similarly, the fall in personal income - that either pushes some individuals into poverty or traps others in poverty - would induce lower personal income tax revenue, unless the government raises the personal income tax rates on rich people so as to compensate for the tax revenue losses due to the poverty rises. However, increasing taxes on rich people might be politically untenable for the government, notably if rich people represents an important electorate for politician in power. Summing-up, we expect that a rise in poverty would likely result in lower tax revenue performance.

The adverse effect of poverty on tax revenue could be severe in the cases negative external shocks on the economy, that can generate greater macroeconomic volatility, including economic growth volatility. Such shocks can result in a substantial rise in poverty rates. For example, macroeconomic volatility, including greater economic volatility reduces welfare in developing countries, with a higher negative effect on poor countries (e.g., Dabla-Norris and Gündüz, 2014; Hnatkovska and Loayza, 2005). Terms of trade shocks can raise poverty rates (e.g., Guillaumont and Puech, 2005; Nkurunziza et al. 2017). Global food prices shocks have resulted in higher poverty rates in low-income countries (e.g., Ivanic and Martin, 2008), and increases in international prices of agricultural commodities have exerted substantial adverse effects on welfare, and significantly raised poverty (e.g., Moncarz et al., 2018). According to Rewilak (2018), currency crises are the most harmful types of crises to the poor. Given the likely negative effect of poverty rates on non-resource tax revenue performance, we argue that the effect of poverty on nonresource tax revenue performance could translate through the economic growth volatility channel. Specially, we expect the magnitude of the negative effect of poverty on non-resource tax revenue performance to increase as the level of economic growth volatility rises.

Overall, on the one hand, we expect that greater export product diversification (or export product concentration) would lead to higher (lower) tax revenue performance. On the other hand, higher poverty rates would be associated with lower tax revenue performance. Thus, export product diversification can result in higher tax revenue performance in countries that experience lower poverty rates. At the same time, one can also argue that the effect of export product diversification on tax revenue performance might, in reality, depend on the poverty rates. In fact, it is possible that higher poverty rates lessen the eventual positive effect of export product diversification on tax revenue performance. This would be particularly the case if export product diversification does not benefit to poor people. In such a scenario, there might a level of poverty above which export product diversification would induce lower tax revenue performance. 


\section{Model specification}

To examine empirically the effect of export product diversification and poverty on tax revenue performance, and the extent to which both factors interact in influencing tax revenue, we build on the extensive literature ${ }^{5}$ on the determinants of tax revenue performance. This literature has pointed out a number of structural factors that matter for the dynamics of public revenue performance. Thus, in addition to our two regressors of interest, namely the indicator of export product concentration, denoted "ECI" and the poverty indicator denoted "POV", we have included in the model specification the following structural factors: the overall level of development, proxied by the real per capita income denoted "GDPC"; the degree of trade openness, denoted "OPEN"; the sectoral composition of domestic output, measured by the share of value added in agriculture in total output, denoted "SHAGRI"; demographic characteristics, such as the size of the total population, denoted "POP". Additionally, many studies have underlined that inflation can also influence tax revenue performance in developing countries. Therefore, we also include a variable capturing the inflation rate in the model. The inflation rate variable has been transformed for reasons explained below. The transformed inflation rate variable is denoted "INFL". Finally, we also include the terms of trade variable in the analysis (see for example, Gnangnon and Brun, 2019) to capture the potential effect of terms of trade movements on tax revenue performance in developing countries.

We expect that the level of development (proxied by the country's real GDP per capita) may be positively relating to public revenue, as it could reflect the fact that the demand for public services would increase with per capita income as well as with a greater economic and institutional sophistication (e.g., Crivelli and Gupta, 2014). We have applied the natural logarithm to the real per capita income so as to reduce its skewness.

On another note, we expect that in light of the difficulties to tax the agriculture sector, a higher share of value added in agriculture in total output would be negatively associated with tax revenue. While some authors (e.g., Balh, 2003) argue that agriculture is not difficult to tax, others such as Tanzi (1992) have contended that a relatively important share of agricultural sector in a country's economy would be associated with a lower need for governmental activities and services, as many public sector activities are city-based. Furthermore, Bird et al. (2008) argue that for

${ }^{5}$ Studies include for example Agbeyegbe et al.( 2006); Bahl (2003); Baunsgaard and Keen (2010); Bird et al. (2008); Brun et al. (2015); Cagé and Gadenne (2018); Crivelli (2016); Crivelli and Gupta (2014, 2018); Ebrill et al. (1999); Ghura (1998); Gnangnon (2018, 2019a); Gnangnon and Brun (2017, 2018, 2019); Khattry and Rao (2002); Langer and Korzhenevych (2019); Morrissey et al. (2016). 
political reasons, some countries exempt a large share of agricultural activities from taxes. From the empirical perspective, virtually all studies have confirmed this theoretical expectation.

The foreign trade sector of the economy measured by the degree of international trade openness of the economy is also an important tax handle. Stotsky and WoldeMariam (1997) have pointed out that certain features of international trade make it more amenable to taxation than domestic activities. In the same vein, Bornhorst et al. (2009), and Drummond et al., (2012) have noted that countries could easily levy taxes at the border. Trade openness can also influence tax revenue through its positive productivity effect ${ }^{6}$ (e.g., Alesina et al., 2005; Grossman and Helpman, 2015; Melitz, 2003), and hence through its enhancing economic growth effect. Nevertheless, Ebrill et al. (1999) and Agbeyegbe et al. (2006) have demonstrated that the impact of trade openness on public revenue depends on several factors, including the structure of trade liberalization and the effect of this structure on the components of tax revenue.

The literature has underlined the importance of the institutional and governance quality for tax revenue performance (e.g., Ghura, 1998; Bird et al. 2004; Bird et al. 2008). Here, we use the level of democracy in a given country as a proxy for the institutional and governance quality. Some works have underlined the close links between the democracy level of a country and its institutional and governance quality (e.g., Charron and Lapuente, 2010; Desbordes and Verardi, 2017; Guerin and Manzocchi, 2009; Rodrik, 2006; Sung, 2004). Greater democratization has been argued, and found, to be positively associated with tax revenue performance (e.g., Acemoglu and Robinson, 2006; Boix, 2001; Gould and Baker, 2002; Yogo and Ngo, 2018). One theoretical reason for this is that as countries democratized, they tend to have better designed tax systems that induce more voluntary tax compliance, and make less use of repressive measures as governing instruments (e.g., Wintrobe, 1990; 1998). The impact of institutional and governance quality on public revenue could be a direct one as well as an indirect one on the efficiency of tax administrations to collect tax revenue. We expect a good institutional and governance quality to be positively related to tax revenue performance.

Terms of trade improvements could generate higher income for trading firms, and hence induce higher tax revenue (e.g., Agbeyegbe et al., 2006).

We also argue that higher inflation can result in lower tax revenue performance (Tanzi, 1977), in particular when the tax system is not protected from inflation. In light of the high skewness of the inflation rate variable, and given that it contains negative values, we have transformed it as follows: INFL $=\operatorname{sign}(I N F L A T I O N) * \log (1+|\operatorname{INFLATION}|)(2)$, where

${ }^{6}$ This positive productivity effect of trade openness can take place through increased competition in domestic markets, knowledge diffusion, market size expansion and the resulting opportunities for economies of scale. 
$\mid$ INFLATION| refers to the absolute value of the annual inflation rate (\%), denoted "INFLATION" (see Yeyati et al. 2007; Gnangnon and Brun, 2019).

Finally, countries' demographic characteristics, proxied by the size of total population, has been introduced in model (1) to capture the fact that tax systems in countries with a rapidly growing population may find it difficult to capture new taxpayers (e.g., Bahl, 2003, p. 13). In that respect, one may expect Accordingly, we expect that the rise in the population size could be negatively associated with tax revenue performance.

Against this background, we postulate the following baseline specification:

$$
\begin{aligned}
& N_{R T A X}=\alpha_{1} \text { NRTAX }_{i t-1}+\alpha_{2} E_{\text {ECI }}+\alpha_{3} \text { POV }_{i t}+\alpha_{4} \log (G D P C)_{i t}+\alpha_{5} O P E N_{i t}+\alpha_{6} \mathrm{INFL}_{i t}+ \\
& \alpha_{7} \text { TERMS }_{i t}+\alpha_{8} \text { SHAGRI }_{i t}+\alpha_{9} \text { INST }_{i t}+\alpha_{10} \log (P O P)_{i t}+\mu_{i}+\gamma_{t}+\omega_{i t}
\end{aligned}
$$

$\mathrm{i}$ and $\mathrm{t}$ represent respectively a country, and the time-period. Model (1) has been estimated using an unbalanced panel dataset of 111 countries, over the period 1980-2014. Following the practice in the empirical literature, we have used non-overlapping sub-periods of 5-year (19801984; 1985-1989; 1990-1994; 1995-1999; 2000-2004; 2005-2009 and 2010-2014), with a view to mitigating the effect of business cycles on variables. $\alpha_{1}$ to $\alpha_{10}$ are coefficients to be estimated. $\mu_{i}$ are countries' time-invariant specific effects; $\gamma_{t}$ are time dummies and stand for global shocks that affect simultaneously all countries' tax revenue performance. $\omega_{i t}$ is a well-behaving error term.

The dependent variable "NRTAX" is the indicator of tax revenue performance, measured here by the ratio (in percentage) of total non-resource tax revenue to the gross domestic product (GDP). It represents the difference between the total tax revenue excluding grants and social contributions (in \% GDP) and the resource tax revenue (in \% GDP), the latter being the tax revenue collected on natural resources. We have used the non-resource tax revenue as a share in GDP rather than the total tax revenue share of GDP because excluding resources tax revenue from total tax revenue allows to ensure homogeneity in the tax revenue variable across countries in the full sample (e.g., Brun et al., 2015).

The first regressor of interest, "ECI" is the Theil index of overall export product concentration computed by the International Monetary Fund (IMF), using the definitions and methods employed by Cadot et al. (2011) (see Appendix 1). Higher values of this index reflect greater export product concentration, while declining values of this index indicate higher degree of export product diversification, i.e., the fact that exports are more homogeneously distributed 
among a series of products. The overall export product concentration is the outcome (i.e., the sum) of the export product concentration at the intensive margins, and the export product concentration at the extensive margins. Export product diversification at the intensive margins signifies a growth in the exports of already existing products, while export product diversification at the extensive margins refers to the growth in the number of active export lines, via new products and new markets. The two components of overall export product concentration are denoted "ECIINT" for export product concentration at the intensive margins, and "ECIEXT" for export product concentration at extensive margins. Higher values of "ECIINT" and "ECIEXT" reflect respectively an increase in the level of export product concentration at the intensive margins and the export product concentration at the extensive margins.

The second key regressor of interest "POV" is the measure of poverty rate. Two indicators of poverty (often used in the empirical literature) have been utilized here as well. These include the poverty headcount ratio at $\$ 1.90$ a day, denoted "POVHC", and the poverty gap at $\$ 1.90$ a day, denoted "POVGAP". The headcount poverty ratio is the main measure of poverty, while the poverty gap rate has been used for robustness check analysis. The poverty headcount at $\$ 1.90 \mathrm{a}$ day represents the percentage of the population living with less than $\$ 1.90$ a day, at 2011 international prices. The poverty gap accounts for the distance of the poor from the poverty line. The poverty gap at $\$ 1.90$ a day (at 2011 international prices) reflects the depth and incidence of poverty, and represents the mean shortfall in income or consumption from the poverty line $\$ 1.90$ a day (counting the nonpoor as having zero shortfall), expressed as a percentage of the poverty line.

All variables (including control variables used in model (1)) are described in Appendix 1. Standard descriptive statistics on all variables are presented in Appendix 2. The list of the 111 countries of the sample is provided in Appendix 3.

\section{Preliminary data analysis}

Using the panel dataset covering the 111 countries and non-overlapping of 5-year average, we present in Figure 1 the development of export product concentration and the tax revenue variable over time. We also display in Figure 2 the developments of the two indicators of poverty and the tax revenue variable. Using the same dataset, we have presented in Figure 3 a simple correlation pattern (in the form of cross-plot) between the indicators of overall export product concentration and non-resource tax revenue share of GDP on the one hand, and between each indicator of poverty and non-resource tax revenue share of GDP, on the other hand. 
We note from Figure 1 that non-resource tax revenue share of GDP has steadily risen, from $12.6 \%$ in $1980-1984$ to $15.6 \%$ in $2010-2014$. At the same time, the indicator of overall export product concentration has declined from 1980-1984 to 1990-1994 (which reflects a tendency for export product diversification). It has then steadily increased over the rest of the period, thereby indicating a tendency for a greater level of export product concentration. Figure 2 indicates that after some fluctuations of poverty indicators from 1980-1984 to 1990-1994, poverty rates have steadily declined over the rest of the period. Figure 3 indicates a negative correlation pattern between overall export product concentration as well as poverty indicators with non-resource tax revenue share.

\section{Empirical approach}

Following previous studies (e.g., Agbeyegbe et al. 2006; Baunsgaard and Keen, 2010; Crivelli, 2016; Crivelli and Gupta, 2014; Gnangnon and Brun, 2018, 2019; Prichard, 2016), the primary estimator used in the empirical analysis is the Blundell and Bond (1998)'s two-step system Generalized Methods of Moments (GMM) estimator. This estimator is particularly suited for dynamic panel datasets like ours, with small time dimension, and a large cross-section dimension (e.g., Roodman, 2006). The two-step system GMM estimator performs better than the firstdifferenced GMM estimator proposed by Arellano and Bond (1991) in particular when variables are persistent, (as in such a case, the first-differenced GMM estimator generates weak instruments) and when the panel dataset is unbalanced (as in this case, gaps are magnified) (e.g., Roodman, 2009). More importantly, this estimator helps handle several endogeneity concerns. These include for example, the omitted variable bias, the endogeneity arising from the correlation between the one-period lag of the dependent variable and the error term, and the endogeneity related to the bidirectional causality between some regressors and the dependent variable. In the present analysis, the possible endogenous regressors include export product concentration and poverty indicators, as well as the institutional and governance quality, and trade openness variables. The utilization of the two-step system GMM estimator involves estimating a system of equations comprising an equation in differences, and an equation in levels, where lagged first differences being used as instruments for the levels equation, and lagged levels being used as instruments for the firstdifference equation.

The consistency of the two-step system GMM estimator is assessed by the Arellano-Bond test of first-order serial correlation in the error term $(\operatorname{AR}(1))$, the Arellano-Bond test of no secondorder autocorrelation in the error term (denoted AR(2)), and the Sargan-Hansen test of over- 
identifying restrictions (OID), the latter being useful in evaluating the validity of the instruments used in the regressions. We have also presented the outcome of the Arellano-Bond test of no second-order autocorrelation in the error term (denoted $\mathrm{AR}(3)$ ). The consistency of this estimator also rests on ensuring that there is no proliferation of instruments (e.g., Bowsher, 2002; Roodman, 2009), as otherwise, the tests mentioned above may lose power. To meet the requirements of the two-step system GMM estimator, the regressions have used 3 lags of the dependent variable as instruments, and 2 lags of endogenous variables as instruments, along with the Windmeijer (2005) corrected standard errors.

While the two-step system GMM estimator is our preferred estimator for performing the empirical analysis, we find useful to estimate a static version of model (1) by means of standard econometric estimators, including the within fixed effects (FE) and the feasible generalized least squares (FGLS). We do this simply to compare the outcomes arising from these estimations with the ones obtained from the two-step system GMM estimator. Note that from now onwards, the estimations of model (1) use alternatively the two indicators of poverty as a measure of the variable "POV", bearing in mind that the poverty headcount indicator is the main indicator, and the poverty gap index is utilized for robustness check analysis.

The outcomes obtained from the estimation of the static specification of model (1) using the FE and FGLS estimators are reported in Table 1.

Tables 2 to 5 report the outcomes arising from the estimation of different specifications of model (1) using the two-step system GMM approach.

Specifically, Table 2 reports the outcomes of the estimation of the dynamic model (1) that includes the overall export product concentration variable "ECI" (see columns [1] and [2], respectively with each of the poverty indicator as a measure of "POV"). In columns [3] and [4] of Table 2, the variable "ECI" has been replaced with each of its components, namely export product concentration at the intensive margins and export product concentration at the extensive margins (note that in these specifications of model (1), the variable "POV" is measured exclusively by the poverty headcount ratio - but results do not change qualitatively and quantitatively when we use alternatively the poverty gap rate).

In Table 3, we present the results that allow investigating how the effects of export product concentration (both overall export product concentration, and each of its two components) and poverty affect non-resource tax revenue share of GDP for varying levels of the real per capita income in the full sample. To obtain these results, we estimate several specifications of model (1) in which we introduce the interaction variable that captures on the one hand, the interaction between the indicator of export product concentration and the real per capita income and, on the 
other hand, the interaction between the poverty indicator and the real per capita income. Note that for the regressions that involve the assessment of how each component of overall export product concentration influences non-resource tax revenue share of GDP as the real per capita income changes, only the poverty headcount ratio has been used as measure of the variable "POV" (results do not change quantitatively or qualitatively when "POV" is measured by the poverty gap rate - these results could be obtained upon request).

Table 4 contains the estimates arising from different specifications of model (1) that allow testing the question at the heart of this analysis, that is, how export product concentration and poverty interacts in influencing non-resource tax revenue share of GDP. These model specifications contain the interaction between each indicator of export product concentration (i.e., the overall export product concentration, and alternatively each of its components) and each poverty indicator.

Finally, the outcomes in Table 5 allow exploring the channels through which export product diversification and poverty affect non-resource tax revenue performance. As discussed in Section 2 , economic growth volatility and economic growth are two indirect channels through which export product concentration can affect non-resource tax revenue. We have also postulated that the effect of poverty on non-resource tax revenue performance can pass through the economic growth volatility channel. The empirical analysis carried out here has used the poverty headcount ratio (our preferred measure of poverty) as the measure of the variable "POV". Note that similar results are obtained when we use the poverty gap rate as the measure of poverty (and can be obtained upon request). To examine empirically whether the effect of export product concentration (or diversification) on non-resource tax revenue performance translates through the economic growth volatility channel, we estimate a variant of model (1) that includes the variable capturing the economic growth volatility as well as its interaction with the overall export product concentration variable. The results of the estimation of this variant of model (1) by means of the two-step system GMM approach are provided in column [1] of Table 5. The variable measuring the economic growth volatility (denoted "GRVOL") has been computed as the standard deviation of the annual economic growth rate (growth rate of real GDP) over each of the aforementioned seven non-overlapping sub-periods of 5-year. We also investigate the extent to which the effect export product concentration (or diversification) on non-resource tax revenue performance depends on the economic growth rate by estimating another variant of model (1) that includes the measure of economic growth rate (i.e., the annual growth rate (\%) of real GDP, denoted "GROWTH") and the interaction between the latter and the indicator of overall export product concentration. Results of the estimation of this model specification are presented in column [2] of 
Table 5. Columns [3] and [4] contain the estimates that allow examining whether the effect of poverty on non-resource tax revenue performance depends on the economic growth rate volatility. Model specifications used to obtain these estimates are model (1) that includes the economic growth volatility variable and the interaction between this variable and each poverty indicator.

\section{Discussion of empirical outcomes}

For the sake of simplicity, we refer in this section to 'non-resource tax revenue share of GDP' as 'non-resource tax revenue'.

The outcomes presented in columns [1] and [2] of Table 1 (i.e., those based on the FE estimator) show no significant effect (at the conventional levels) of overall export product concentration on non-resource tax revenue. In the same two columns, the two indicators of poverty influence negatively and significantly (at the $1 \%$ level) non-resource tax revenue, although the magnitude of this negative effect is higher for "POVGAP" than for "POVHC". This signifies, as expected theoretically, that higher poverty rates are associated with lower non-resource tax revenue. Concerning control variables in the two columns of this Table, we observe that higher trade openness, lower inflation rates, terms of trade improvements, and a lower share of value added in agriculture in total output exert a positive and significant effect (at the $1 \%$ level) on nonresource tax revenue. The other control variables do not affect significantly non-resource tax revenue.

Turning to results in columns [3] and [4] of Table 1 (those based on the FGLS approach), we find that the overall export product concentration and poverty indicators are negatively and significantly (at the 1\% level) associated with non-resource tax revenue. These confirm our theoretical expectations that both greater export product concentration and higher poverty levels induce lower non-resource tax revenue. Estimates related to poverty indicators are slightly lower than those obtained in columns [1] and [2] of Table 1. The difference in the results (arising from the FE and FGLS estimators) concerning the overall export product concentration can be due to the fact that in contrast with the FGLS approach, the FE estimator disregards the between-country variation in the variable "ECI" and takes only into account the within-country variation of this variable, whereas the latter exhibits a strong between-country variation (as it changes slightly over time - it takes time for countries to diversify their export product baskets). Results related to control variables in columns [3] and [4] of Table 1 show that the positive drivers (including at the $1 \%$ level) of non-resource tax revenue include higher real per capita income, greater trade 
openness, lower inflation rates, lower share of value added in agriculture in total output, lower population size, and surprisingly lower institutional and governance quality. The terms of trade variable does not appear to influence significantly non-resource tax revenue performance. As underlined in the previous section, these estimates in Table 1 are likely biased given the possible endogeneity concerns that can plague the dynamic model (1).

We note from all columns of Tables 2 to 5 that the one-period lag of the dependent variable is always positive and significant at the $1 \%$ level. This highlights the persistence of the nonresource tax revenue over time, and thus, the need for considering a dynamic specification of model (1) in the analysis. Additionally, the OID test and the autoregressive AR(1), AR(2), and $\operatorname{AR}(3)$ tests have yielded expected outcomes. Specially, the p-values of the AR(1) are lower than 0.05 , while the $\operatorname{AR}(2)$ and $\operatorname{AR}(3)$ tests yield p-values higher than 0.10 . The p-values of the OID test are also always higher than 0.10 . Overall, these outcomes indicate that the two-step system GMM estimator is appropriate to conduct the empirical analysis.

Turning now to results in Table 2, we note from columns [1] and [2] that both the overall export product concentration, and the two poverty indicators exert a negative and significant effect (at the 1\% level) on non-resource tax revenue share in GDP. The estimates associated with the variable "ECI" are lower than those reported in columns [3] and [4] of Table 1. At the same time, estimates related to poverty indicators are different from those in the four columns of Table 1, although they are more closed in magnitude to estimates in columns [1] and [2] of Table 1 than to those in columns [3] and [4] of Table 1. Findings in columns [1] and [2] of Table 2 confirm our theoretical expectations that greater export product concentration and a rise in poverty rates induce lower non-resource tax revenue performance in developing countries. Focusing on results in column [1] of Table 2, we find that a 1-point increase in the index of overall export product concentration induces a 0.88 -point decline in non-resource tax revenue. In other words, an increase in the index of overall export product concentration by a one standard deviation is associated with a 0.98 point $\left(=1.117^{*} 0.876\right)$ fall in non-resource tax revenue. Likewise, a 1-point increase in the poverty headcount ratio generates a 0.08 -point fall in non-resource tax revenue. Put it differently, an increase in the poverty headcount ratio by a one standard deviation results in a decline of non-resource tax revenue by a 1.97 point $(=25.986 * 0.076)$. Results in column [2] show that a 1 -point increase in the poverty gap rate induces a 0.10 -point fall in non-resource tax revenue. Thus, an increase in the poverty gap rate by a one standard deviation results in a fall in the nonresource tax revenue by a 1.3 point $\left(=12.866^{*} 0.102\right)$. Estimates related to control variables in columns [1] and [2] suggest that at the 5\% level, lower inflation, improvements in terms of trade, and lower population size are positively and significantly associated with non-resource tax revenue 
performance. An improvement in the institutional and governance quality exerts a positive effect on non-resource tax revenue performance (see results in column [2] of Table 2). The coefficient of the variable capturing the share of value added in agriculture in total output is yet negative, as expected, but not significant at the conventional levels. Similarly, trade openness does not affect non-resource tax revenue. However, real per capita income appears to be negatively and significantly associated with non-resource tax revenue performance. This surprising outcome aligns with the findings by Gnangnon and Brun (2017). The latter have obtained a negative impact of the real per capita income on non-resource tax revenue, using a panel dataset containing both developed and developing countries. This indicates that less developed countries performed better in terms of non-resource tax revenue share of GDP than relatively more advanced economies among developing countries. One possible explanation for this outcome can be that an improvement in the real per capita income might not be sufficient to explain the differences between countries' non-resource tax revenue performance in the sample. For example, a higher real per capita income could contribute to enhancing non-resource tax revenue performance when the institutional quality and governance concomitantly improves. We do not go further into this analysis, as it is not the topic at the heart of the present study.

Results in columns [3] and [4] of Table 2 show that the poverty indicator (here poverty headcount ratio) still holds negative and significant coefficient. However, the negative effect of overall export product concentration on non-resource tax revenue performance found in column [1] of Table 2 reflects a negative and significant (at the 1\% level) effect of export product concentration at the intensive margins on non-resource tax revenue, and a positive and significant effect of export product concentration at the extensive margins on non-resource tax revenue. These suggest that export product diversification at the intensive margins enhances non-resource tax revenue performance, whereas export product concentration at the extensive margins influences it positively. However, these findings certainly hide differentiated effects across countries in the full sample. This is what we will examine in Table 3. Before moving to results in this Table, we note here that a 1-point increase in the index of export product concentration at the intensive margins is associated with a 0.95 -point decline in non-resource tax revenue. Expressed differently, a rise in the index of export product concentration at the intensive margins by a 1 standard deviation (i.e., 0.979) leads to a fall in non-resource tax revenue by 0.93 point (= $0.979 * 0.953$ ). For export product concentration at the intensive margins, a 1-point increase in this index leads to a 0.89 -point rise in non-resource tax revenue. Alternatively, an increase in the index of export product concentration at the extensive margins by a 1 standard deviation (i.e., 0.549) results in a rise in non-resource tax revenue by 0.49 point $(=0.886 * 0.549)$. 
Turning now to Table 3, we note from columns [1] and [2] that the coefficient of "ECI" is positive and significant at the $1 \%$ level, while the interaction term of the variable ["ECI* $\log (\mathrm{GDPC}) "]$ is negative and significant at the $1 \%$ level. The combination of these two outcomes indicates that there is a threshold of the real per capita income above which the total effect of overall export product concentration changes sign, that is, becomes negative; otherwise it is positive. Focusing on results in column [1] of Table 3, we find that this threshold amounts to US $\$ 1533$ [=exponential (8.846/1.206)]. Hence, for countries whose real per capita income is lower than US\$1533 (i.e., this category primarily includes low-income countries), overall export product concentration exerts a positive and significant effect on non-resource tax revenue. Additionally, among these countries, the lower the real per capita income, the higher is the magnitude of the positive effect of overall export product concentration on non-resource tax revenue. This finding aligns with that of Gnangnon and Brun (2017) who have also obtained that overall export product concentration influences positively non-resource tax revenue in low-income countries. This outcome can be explained by the fact that in low-income countries, trading firms contribute significantly to improving tax revenue performance through their export earnings that rely heavily on primary commodities. In such a context, one could expect that export product concentration (including on primary commodities) would be associated with higher non-resource tax revenue.

Countries whose real per capita income exceeds US\$1533 experience a positive effect of overall export product diversification on non-resource tax revenue, and the higher the real per capita income, the greater is the magnitude of the positive effect of export product diversification on non-resource tax revenue.

Meanwhile, results in column [1] of Table 3 indicate that the coefficient of "POVHC" is negative and significant at the $1 \%$ level, and the interaction term of the variable ["POVHC*Log(GDPC)"] is positive and significant at the $1 \%$ level. Taken together, these two outcomes suggest that the total effect of poverty headcount ratio on non-resource tax revenue changes once the real per capita income exceeds the threshold of US $\$ 7047.3$ [=exponential $(0.311 / 0.0351)]$. Thus, a rise in poverty headcount ratio influences negatively non-resource tax revenue in countries whose real per capita income is lower than US\$ 7047.3. For this set of countries, the magnitude of this negative effect rises as the real per capita income declines, i.e., low-income countries experience a higher negative effect of poverty headcount ratio on nonresource tax revenue than relatively advanced countries in the full sample. However, in countries with a real per capita income higher than the US\$7047.3, poverty headcount ratio exerts a positive effect on non-resource tax revenue. For this group of countries, the magnitude of the positive effect of poverty headcount ratio on non-resource tax revenue increases as the real per capita 
income rises. These findings can be explained by the fact that in contrast with countries with a real per capita income lower than US\$7047.3, those whose real per capita income exceed US\$ 7047.3 are more capable of compensating the negative effect of higher poverty rates on non-resource tax revenue. They can do so by increasing tax rates on richer people (if such a measure can be politically acceptable), or reducing tax relief and tax exemptions granted to the segment of rich people in the population. Results in column [2] of Table 3 concerning the total effect of poverty gap on non-resource tax revenue display similar patterns to those concerning the non-resource tax revenue effect of poverty headcount ratio. In fact, we also find a negative and significant (at the $1 \%$ level) coefficient of "POVGAP", and a positive and significant (also at the $1 \%$ level) interaction term of the variable ["POVGAP* $\log (\mathrm{GDPC}) "]$. Therefore, the reasoning above also applies here as well, with the difference being that the threshold of the real per capita income above which the total effect of poverty gap on non-resource tax revenue changes sign is US\$2512 [=exponential $(0.494 / 0.0631)]$.

Overall, the key messages from columns [1] and [2] of Table 3 are that export product diversification contributes to enhancing non-resource tax revenue performance in relatively advanced developing countries, while in low-income countries, it is rather export product concentration that influences positively non-resource tax revenue. Additionally, poverty tends to affect negatively non-resource tax revenue in less developed countries, while in relatively 'advanced' developing countries, it is positively associated with non-resource tax revenue.

The outcomes in columns [3] and [4] of Table 3 suggest that the effect of each component of the overall export product concentration on non-resource tax revenue depends on countries' real per capita income. In fact, we note from the two columns that the coefficients of "ECIINT" and "ECIEXT" are both positive and significant respectively at the 5\% level, and the $1 \%$ level, whereas the interaction terms related to the relevant interaction variables are negative and significant at the $1 \%$ level. Based on these outcomes, we conclude that both export product diversification at the intensive margins, and at the extensive margins exert a positive and significant effect on non-resource tax revenue only when the real per capita income exceeds a certain level. This threshold amounts to US\$ 948.4 [=exponential (4.154/0.606)] (for the outcomes based on export product concentration at the intensive margins) and US\$ 1408.7 [=exponential (9.440/1.302)] (for the outcomes based on export product concentration at the extensive margins). Hence, it is still for relatively low-income countries that export product concentration either at the intensive margins or at the extensive margins, induces a higher non-resource tax revenue performance. These findings line up with the previous one, whereby overall export product concentration is positively associated with non-resource tax revenue in relatively low-income 
countries. In contrast, countries whose real per capita income exceeds US\$ 948.4 and US\$ 1408.7 experience respectively a positive non-resource revenue effect of both export product diversification at the intensive margins, and export product diversification at the extensive margins. For these countries, the magnitude of this positive effect rises with the real per capita income.

Considering now estimates in Table 4, we note that across columns [1] and [2], the coefficients of the interaction variables ["ECI*POVHC"] and ["ECI*POVGAP"] are positive and significant at the $1 \%$ level. These suggest that export product diversification is positively associated with non-resource tax revenue in countries that experience lower poverty rates. Alternatively, a fall in poverty rates influences positively non-resource tax revenue in countries that diversify their export products basket. As reported at the bottom of Table 4, the thresholds of poverty headcount ratio and poverty gap rate above which export product diversification exerts a negative effect on non-resource tax revenue performance, are respectively 55.2 and 27.1. To recall, the maximum values of the variables "POVHC" and "POVGAP" in the full sample are respectively 94.4 and 64.5 (see Appendix 2). Therefore, we can conclude that as long as poverty headcount rates are lower than 55.22 or poverty gap rates are lower than 27.07 , export product diversification induces a greater non-resource tax revenue performance, and the magnitude of this positive effect rises as poverty rates become lower. Conversely, when poverty headcount and poverty gap rates exceed the respective thresholds 55.2 and 27.1, export product diversification becomes negatively associated with non-resource tax revenue performance, and the higher the poverty rate, the greater is the magnitude of the negative effect of export product diversification on non-resource tax revenue.

In a nutshell, the take-home message of columns [1] and [2] of Table 4 is that export product diversification and poverty genuinely interacts in influencing non-resource tax revenue performance in developing countries. Export product diversification leads to higher non-resource tax revenue when poverty rates are relatively low, as for higher poverty rates, it induces lower nonresource tax revenue performance.

Results in columns [3] and [4] of Table 4 show that the interaction terms are not significant at the $5 \%$ level. These outcomes reveal that the effect of export product concentration at the intensive margins on non-resource tax revenue performance does not depend on the level of poverty. Thus, the findings drawn from the estimates in columns [1] and [2] of Table 4 concerning how the overall export product diversification and poverty interact in influencing non-resource tax revenue performance, are not driven by export product diversification at the intensive margins, but instead by export product diversification at the extensive margins, as shown by results in columns [5] and [6] of the same Table. We observe in these two latter columns that the coefficients 
of both ["ECIEXT*POVHC"] and ["ECIEXT*POVGAP"] are significant at the $1 \%$ level. These signify that export product diversification at the extensive margins exerts a positive effect on nonresource tax revenue performance in countries that experience lower poverty rates. Given that the coefficients of "ECIEXT" are negative and significant (at the 1\% level) in columns [5] and [6] of Table 4, we conclude that export product diversification at the extensive margins influences positively non-resource tax revenue performance only when the poverty rate is below a certain threshold. The latter amounts to 29.6 and 13.2 respectively for poverty headcount and poverty gap indicators (see the bottom columns [5] and [6] of Table 4).

Finally, we examine the outcomes in Table 5. In column [1] of this Table, we observe that the coefficient of the interaction variable ["ECI*GRVOL"] is negative and significant at the $1 \%$ level, while the variable "ECI" exhibits a positive but not significant coefficient at the conventional levels. Thus, the overall export product concentration induces lower non-resource tax revenue performance in countries that experience a higher economic growth volatility, and the greater the level of economic volatility, the higher is the magnitude of the negative effect of export product concentration on non-resource tax revenue performance. This also means that greater overall export product diversification contributes to enhancing non-resource tax revenue performance in the context of higher economic growth volatility.

We also obtain from column [2] of Table 5 that the interaction term of ["ECI*GROWTH"] is not significant at the conventional levels, whereas the coefficient of "ECI" is negative and significant at the $1 \%$ level. Therefore, we deduce that the effect of export product diversification on non-resource tax revenue performance does not pass through the economic growth channel. In addition, regardless of the level of economic growth, export product diversification always leads to a higher non-resource tax revenue performance.

Estimates in column [3] of Table 5 show negative and significant coefficients (at the 1\% level) of both ["POVHC*GRVOL"] and "POVHC" variables. Similarly, as per results in column [4] of Table 5, the interaction term of the variable ["POVGAP*GRVOL"] is negative and significant at the $1 \%$ level, while the coefficient of the variable "POVGAP" is not significant at the conventional levels. Taken together, these results indicate that the effect of poverty (poverty headcount or poverty gap) on non-resource tax revenue genuinely depends on the degree of economic growth volatility. In fact, regardless of the degree of economic growth volatility, poverty always influences negatively non-resource tax revenue performance. But, the magnitude of this adverse effect rises with the level of economic growth volatility.

Results concerning control variables in Tables 3 to 5 are largely consistent with those in Table 2, particularly in columns [1] and [2] of Table 2. 


\section{Conclusion}

This paper has investigated the effect of export product diversification and poverty on nonresource tax revenue in developing countries. The empirical analysis has established interesting findings. First, export product diversification leads to higher non-resource tax revenue performance in advanced developing economies, while for relatively less developed countries, it is export product concentration that induces greater non-resource tax revenue performance. Second, higher poverty rates lead to lower non-resource tax revenue performance in less developed countries, but induces higher non-resource tax revenue performance in relatively 'advanced' developing countries. Third, the effect of export product diversification and poverty on nonresource tax revenue performance translates through the economic growth volatility channel. Greater export product diversification helps to reduce the adverse effect of economic growth volatility on non-resource tax revenue. Higher poverty rates consistently reduce non-resource tax revenue performance in countries that experience a higher degree of economic growth volatility. Fourth, the effect of export product diversification on non-resource tax revenue performance depends on the level of poverty. In fact, export product diversification is associated with higher non-resource tax revenue performance in countries that experience lower poverty rates.

The findings of the present study show that reducing poverty and enhancing export product diversification would contribute to the improvement of non-resource tax revenue performance in developing countries. These positive non-resource tax revenue performance effects of export product diversification and lower poverty rates would particularly be strong in countries where governments endeavour to enhance tax and customs administrations efficiency, design appropriate tax policy, and improve voluntary tax compliance. 


\section{References}

Abdelwahed, L. (2020). More oil, more or less taxes? New evidence on the impact of resource revenue on domestic tax revenue. Resources Policy, 68, 101747.

Acemoglu D. and J. A. Robinson (2006) Economic Origins of Dictatorship and Democracy, Cambridge University Press.

Acemoglu, D., Johnson, S., Robinson, J. A., and Thaicharoen, Y. (2003). Institutional Causes, Macroeconomics Symptoms: Volatility, Crises, and Growth. Journal of Monetary Economics, 50(1), 49-122.

Aditya, A., and Acharyya, R. (2013). Export Diversification, Composition, and Economic Growth: Evidence from Cross-country Analysis. Journal of International Trade and Economic Development 22, 959-992.

Agbeyegbe, T. D., Stotsky, J. and WoldeMariam, A. (2006). Trade liberalization, exchange rate changes, and tax revenue in Sub-Saharan Africa. Journal of Asian Economics, 17(2) 261-284.

Alesina, A, Spolaore, E, Wacziarg, R. (2005). Trade, growth and the size of countries. In P Aghion, S Durlauf (Eds.), Handbook of economic growth, (pp. 1499-1542). Amsterdam: Elsevier.

Alimi, N. (2016). Volatility and growth in developing countries: An asymmetric effect. The Journal of Economic Asymmetries, 14(B), 179-188.

Antonakakis, N. and Badinger, H. (2016). Economic growth, volatility, and cross-country spillovers: New evidence for the G7 countries. Economic Modelling, 52(B),352-365.

Arellano, M., and Bond, S. (1991). Some Tests of Specification for Panel Data: Monte Carlo Evidence and an Application to Employment Equations. Review of Economic Studies, 58, $277-$ 297.

Athukorola, P. C. (2000). Manufacturing exports and terms of trade of developing countries: evidence from Sri Lanka. Journal of Development Studies, 36, 89-104.

Badinger, H. (2010). Output volatility and economic growth. Economics Letters, 106(1), 15-18.

Bahl, R. W. (2003). 'Reaching the Hardest to Tax: Consequences and Possibilities'. Paper presented at the 'Hard to Tax: An International Perspective' conference, Andrew Young School of Policy Studies, Georgia State University, May 15-16.

Bain, L.E., Awah, P.K., Geraldine, N., Kindong, N.P., Siga, Y., Bernard, N., and Tanjeko, A.T. (2013). Malnutrition in sub-saharan africa: burden, causes and prospects. Pan African Medical Journal 15 (120).

Balabanis, G. I. (2001). The Relationship Between Diversification and Performance in Export Intermediary Firms. British Journal of Management, 12(1), 67-84.

Baunsgaard, T., and Keen, M. (2010). Tax Revenue and (or?) Trade Liberalization. Journal of Public Economics, 94(9-10), 563-577. 
Berument, M.H., Dincer, N.N., and Mustafaoglu, Z. (2012). Effects of growth volatility on economic performance - Empirical evidence from Turkey. European Journal of Operational Research, 217(2), 351-356.

Besley, T., and Persson, T. (2014). Why Do Developing Countries Tax So Little? Journal of Economic Perspectives, 28(4), 99-120.

Bird, R. M., Martinez-Vazquez, J. and Torgler, B. (2008). Tax Effort in Developing Countries and High-Income Countries: The Impact of Corruption, Voice and Accountability, Economic Analysis and Policy, 38(1), 55-71.

Bird, R. M., Martinez-Vazquez, J., \& Torgler, B. (2004). Societal institutions and tax effort in developing countries. International Studies Program Working Paper, 04-06.

Blocker, C.P., Ruth, J.A., Sridharan, S., Beckwith, C., Ekici, A., Goudie-Hutton, M., Rosa, J. A., Saatcioglu, B., Talukdar, D., Trujillo, C., and Varmank, R. (2013). Understanding poverty and promoting poverty alleviation through transformative consumer research. Journal of Business Research, 66(8), 1195-1202.

Blundell, R., and Bond, S. (1998). Initial Conditions and Moment Restrictions in Dynamic Panel Data Models. Journal of Econometrics, 87, 115-143.

Boix, C. (2001). Democracy, Development, and the Public Sector. American Journal of Political Science, 45(1), 1-17.

Bornhorst, F., Gupta, S. and Thornton, J. (2009). Natural Resource Endowments and the Domestic Revenue Effort. European Journal of Political Economy 25, 439-446.

Bowsher, C.G. (2002). On testing overidentifying restrictions in dynamic panel data models. Economics Letters 77(2), 211-220.

Breunig, R., and Majeed, O. (2020). Inequality, poverty and economic growth. International Economics, 161, 83-99.

Brun J.F., Chambas, G., and Mansour, M. (2015). Tax Effort of Developing Countries: An Alternative Measure, In: Financing Sustainable Development Addressing Vulnerabilities, Chapter 11. Edited by Boussichas, M., and Guillaumont, P., Economica. FERDI.

Cadot, O., Carrere, C., and Strauss-Kahn, V. (2011). Export Diversification: What's Behind the Hump? Review of Economics and Statistic, 93, 590-605.

Cagé, J., and Gadenne, L. (2018). Tax revenues and the fiscal cost of trade liberalization, 17922006, 1792-2006. Explorations in Economic History, 70, 1-24.

Camanho da Costa Neto, N., and Romeu, R. (2011). Did export diversification soften the impact of the global financial crisis?. International Monetary Fund Working Paper WP/11/99, International Monetary Fund, Washington, D.C. 
Campi, M., and Dueñas, M. (2020). Volatility and economic growth in the twentieth century. Structural Change and Economic Dynamics, 53, 330-343.

Can, M., and Gozgor, G. (2017). Causal Linkages among the Product Diversification of Exports, Economic Globalization and Economic Growth. Review of Development Economics, 21(3), 888908.

Chakravarti, D. (2006). Voices Unheard: The Psychology of Consumption in Poverty and Development. Journal of Consumer Psychology, 16(4), 363-376.

Charron, N., and Lapuente, V. (2010). Does democracy produce quality of government? European Journal of Political Research, 49(4), 443-470.

Crivelli, E. (2016). Trade liberalization and tax revenue in transition: an empirical analysis of the replacement strategy. Eurasian Economic Review, 6,1-25.

Crivelli, E. and Gupta, S. (2014). Resource blessing, revenue curse? Domestic revenue effort in resource-rich countries. European Journal of Political Economy, 35, 88-101.

Crivelli, E. and Gupta, S. (2018). IMF conditionality supports revenue collection: is it just tax rates? Applied Economics Letter, 25(12), 882-885.

Dabla-Norris, E., and Gündüz, Y. B. (2014). Exogenous Shocks and Growth Crises in LowIncome Countries: A Vulnerability Index. World Development, 59, 360-378.

del Rosal, I. (2019). Export diversification and export performance by destination country. Bulletin of Economic Research, 71(1), 58-74.

Desbordes, R., and Verardi, V. (2017). Foreign Direct Investment and Democracy: A Robust Fixed Effects Approach to a Complex Relationship. Pacific Economic Review, 22(1), 43-82.

di Giovanni, J., Levchenko, A., and Méjean, M. (2014). Firms, destinations and aggregate fluctuations. Econometrica, 82(4),1303-1340.

Dreher, A. (2006). Does globalisation affect growth? Evidence from a new index of globalisation. Applied Economics, 38(10), 1091-1110.

Ebrill, L., Stotsky, J. and Gropp, R. (1999). Revenue implications of trade liberalization, Occassional Paper, 180. International Monetary Fund, Washington, DC.

Fata, A. (2002). "The Effects of Business Cycles on Growth." In N. Loayza and R. Soto, eds., Economic Growth: Sources, Trends, and Cycles. Santiago, Chile: Central Bank of Chile.

Funke, M. and Ruhwedel, R. (2001). Export variety and export performance: empirical evidence from East Asia. Journal of Asian Economics, 12, 493-505.

Funke, M. and Ruhwedel, R. (2002). Export variety and export performance: empirical evidence for the OECD Countries. Review of World Economics, 138, 97-114. 
Ghura, H. (1998). Tax Revenue in sub-Sahara Africa: Effects of economic policies and corruption. International Monetary Fund (WP/98/135. Washington D.C).

Gnangnon, S. K. (2019a). Financial Development and Tax Revenue in Developing Countries: Investigating the International Trade and Economic Growth Channels. EconStor Preprints 206628, ZBW - Leibniz Information Centre for Economics.

Gnangnon, S. K. (2019b). Poverty and export product diversification in developing countries. Journal of International Trade \& Economic Development, 29(2), 211-236.

Gnangnon, S. K. (2019c). Do Poverty Rates matter for the degree of Trade Openness in Developing Countries? Journal of International Commerce, Economics and Policy, see online at: https://onlinelibrary.wiley.com/doi/abs/10.1111/1467-8454.12200?af =R

Gnangnon, S.K. (2018). Export Product Diversification and Public Revenue's Dependence on Resource Revenue. International Economic Journal, 32(3), 372-391.

Gnangnon, S.K. (2020). Export product diversification and tax performance quality in developing countries. International Economics and Economic Policy, https://doi.org/10.1007/s10368-02000462-6

Gnangnon, S.K., and Brun, J-F. (2017). Impact of export upgrading on tax revenue in developing and high-income countries. Oxford Development Studies, 45(4), 542-561.

Gnangnon, S.K., and Brun, J-F. (2018). Impact of bridging the Internet gap on public revenue mobilization. Information Economics and Policy, 43, 23-33.

Gnangnon, S.K., and Brun, J-F. (2019). Trade openness, tax reform and tax revenue in developing countries. The World Economy, 42(12), Special Issue: Global Policy Review, 3515-3536.

Gould, A.C., and Baker, P.J. (2002). Democracy and Taxation. Annual Review of Political Science, $5,87-110$.

Grossman, G.M., and Helpman, E. (2015). Globalization and growth. American Economic Review, 105(5), 100-104.

Guerin, S. S., and Manzocchi, S. (2009). Political regime and FDI from advanced to emerging countries. Review of World Economics, 145(1), 75-91.

Guillaumont, P., and Puech, F. (2005). L'instabilité macroéconomique comme facteur de criminatlité. Working Papers 200519, CERDI, Clermont-Ferrand, France.

Gygli, S., Haelg, F., Potrafke, N., and Sturm, J-E. (2019). The KOF Globalisation Index - Revisited. Review of International Organizations, 14, 543-574.

Haddad, M., Lim, J. J., Pancaro, C., and Saborowski, C. (2013). Trade openness reduces growth volatility when countries are well diversified. Canadian Journal of Economics, 46(2), 765-790.

Haushofer, J., and Fehr, E. (2014). On the Psychology of Poverty. Science, 344(6), 862-867. 
Hausmann, R., Hwang, J., and Rodrik, D. (2007). What you export matters. Journal of economic growth, 12(1), 1-25.

Herzer, D., and Nowak-Lehmann, F. D. (2006). What Does Export Diversification Do for Growth? An Econometric Analysis. Applied Economics, 38(15), 1825-1838.

Hill, M. S., and Sandfort, J. R. (1995). Effects of childhood poverty on productivity later in life: Implications for public policy. Children and Youth Services Review, 17(1-2), 91-126.

Hnatkovska, V., and Loayza, N. (2005). "Volatility and Growth." In J. Aizenmann and B. Pinto, eds., Managing Economic Volatility and Crises. Cambridge, United Kingdom: Cambridge University Press. 65-100.

Khattry, B., and Rao, J.M. (2002). Fiscal Faux Pas?: An analysis of the revenue implications of trade liberalization, World Development, 30(8), 1431-1444.

Kramarz, F., Martin, J., and Mejean, I. (2020). Volatility in the small and in the large: The lack of diversification in international trade. Journal of International Economics, 122, Article 103276.

Langer, S., and Korzhenevych, A. (2019). Tax revenue potential and effort: Worldwide estimates using a new dataset. Economic Analysis and Policy, 63, 119-129.

Lee, D. and Zhang H. (2019). Export diversification in low-income countries and small states: Do country size and income level matter?. IMF Working Paper No. 19-118, Washington, D.C.

Lichand, G., Bettinger, E., Cunha, N., and Madeira, R. (2020). The Psychological Effects of Poverty on Investments in Children's Human Capital. University of Zurich, Department of Economics, Working Paper No. 349, Switzerland.

López, H. (2006). Does poverty matter for growth. In: Perry, G.E., Arias, O.S., López, J.H., Maloney, W.F., Servén, L. (Eds.), Poverty Reduction and Growth: Virtuous and Vicious Circles. World Bank Publications, Washington, DC, pp. 103-128. chapter 6.

Malik, A., and Temple, J. R. W. (2009). The geography of output volatility. Journal of Development Economics, 90(2), 163-178.

Mania, E., and Rieber, A. (2019). Product export diversification and sustainable economic growth in developing countries. Structural Change and Economic Dynamics, 51, 138-151.

Marshall, M.G., Gurr, T.R., and Jaggers, K. (2018). Polity IV Project: Political Regime Characteristics and Transitions, 1800-2017. Centre for Systemic Peace: Vienna, VA.

Melitz, M.J. (2003). The impact of trade on intra-industry reallocations and aggregate industry productivity. Econometrica, 71(6), 1695-1725.

Moncarz, P., Barone, S., and Descalzi, R. (2018). Shocks to the international prices of agricultural commodities and the effects on welfare and poverty. A simulation of the ex-ante long-run effects for Uruguay. International Economics, 156, 136-155. 
Morrissey, O., Von Haldenwang, C., Von Schiller, A., Ivanyna, M., and Bordon, I. (2016). Tax Revenue Performance and Vulnerability in Developing Countries. The Journal of Development Studies, 52(12), 1689-1703.

Nakabashi, L. (2018). Poverty and economic development: Evidence for the Brazilian states. EconomiA, 19, 445-458.

Naudé, W., Bosker, M., and Matthee, M. (2010). Export Specialization and Local Economic Growth. World Economy, 33(4), 552-572.

Naudé, W. A., and Rossouw, R. (2011). Export Diversification and Economic Performance: Evidence from Brazil, China, India and South Africa. Economic Change and Restructuring, 44 (1), $99-134$.

Njikam, O. (2017). Export market destination and performance: Firm-level evidence from SubSaharan Africa. Journal of African Trade, 4(1-2), 1-19.

Nkurunziza, J. D., Tsowou, K., and Cazzaniga, S. (2017). Commodity Dependence and Human Development. African Development Review, 29(S1), 27-41.

Oz-Yalaman, G. (2019). Financial inclusion and tax revenue. Central Bank Review, 19(3), 107-113.

Prebisch, R. (1950). The economic development of Latin America and its principal problems. Economic Bulletin for Latin America, 7, 1-12.

Prichard, W. (2016). Reassessing Tax and Development Research: A New Dataset, New Findings, and Lessons for Research. World Development, 80, 48-60.

Pugliese, E., Chiarotti, G. L., Zaccaria, A., and Pietronero, L. (2017). Complex Economies Have a Lateral Escape from the Poverty Trap. PLoS ONE 12(1): e0168540.

Ramey, G., and Ramey, V. (1995). Cross Country Evidence on the Link between Volatility and Growth. American Economic Review, 85(5), 1138-51.

Ravallion, M. (2012). Why don't we see poverty convergence? American Economic Review, 102 (1), 504-523.

Ravallion, M. (2016). The Economics of Poverty: History, Measurement, and Policy. Oxford University Press, New York, NY.

Redding, S. (1999). Dynamic Comparative Advantage and the Welfare Effects of Trade. Oxford Economic Papers 51, 15-39.

Rewilak, J. (2018). The impact of financial crises on the poor. Journal of International Development, 30 (1), 3-19.

Rodrik, D. (1996). Understanding economic policy reform. Journal of Economic Literature, 34(1), $9-41$. 
Roodman, D. (2006). How to do xtabond2: An introduction to difference and system GMM in stata. Center for Global Development, Working Paper, (103).

Roodman, D. M. (2009). A note on the theme of too many instruments, Oxford Bulletin of Economic and Statistics, 71(1), 135-158.

Santos-Paulino, A.U. (2017). Estimating the impact of trade specialization and trade policy on poverty in developing countries. The Journal of International Trade and Economic Development, 26(6), 693-711.

Singer, H. (1950). The distribution of gains between investing and borrowing countries. American Economic Review, Papers and Proceedings of the Sixty-second Annual Meeting of the American Economic Asociation (May, 1950), 40(2), 473-485.

Solano, L. V. L., Brümmer, B., Engler, A., and Otter, V. (2019). Effects of intra- and inter-regional geographic diversification and product diversification on export performance: Evidence from the Chilean fresh fruit export sector. Food Policy, 86, Article 101730.

Squalli, J., and Wilson, K. (2011). A New Measure of Trade Openness. The World Economy, 34(10), 1745-1770.

Stanley, D. L., and Bunnag, S. (2001). A new look at the benefits of diversification: lessons from Central America. Applied Economics, 33, 1369-83.

Stotsky, J. G. and WoldeMariam, A. (1997). Tax effort in Sub-Saharan Africa. IMF Working Paper, WP/97/107, Washington, DC.

Songwe, V., and Winkler, D. (2012). Exports and Export Diversification in Sub-Saharan Africa: Strategy for Post-Crisis Growth. Africa Growth Initiative, Brookings Institution.

Sung, H.-E. (2004). Democracy and political corruption: A cross-national comparison. Crime, Law and Social Change, 41(2), 179-193.

Tanzi, V. (1977). Inflation, Lags in Collection, and the Real Value of Tax Revenue. Staff Papers. International Monetary Fund, 26, 154-67, Washington D.C.

Tanzi, V. (1992). 'Structural Factors and Tax Revenue in Developing Countries: A Decade of Evidence', in I. Goldin and L. A. Winters (eds.), Open Economies: Structural Adjustment and Agriculture. Cambridge: Cambridge University Press: 267-281.

Tosun, M. S., and Abizadeh, S. (2007). Economic growth and tax components: an analysis of tax changes in OECD. Applied Economics, 37(19), 2251-2263.

United Nations Conference on Trade and Development (UNCTAD) (2018). Exports Diversification and Employment in Africa. UNCTAD/ALDC/2018/3, Geneva, Switzerland.

Vannoorenberghe, G., Wang, Z., and Yu, Z. (2016). Volatility and diversification of exports: Firmlevel theory and evidence. European Economic Review, 89, 216-247. 
Weinberger, K., and Lumpkin, T.A. (2007). Diversification into Horticulture and Poverty Reduction: A Research Agenda. World Development, 35(8), 1464-1480.

Windmeijer, F. (2005). A finite sample correction for the variance of linear efficient two-step GMM estimators. Journal of Econometrics, 126(1), 25-51.

Wintrobe, R. (1990). The Tinpot and the Totalitarian: An Economic Theory of Dictatorship. American Political Science Review, 84, 849-72.

Wintrobe, R. (1998) The Political Economy of Dictatorship, Cambridge University Press.

Xuefeng, Q., and Yaşar, M. (2016). Export Market Diversification and Firm Productivity: Evidence from a Large Developing Country. World Development, 82, 28-47.

Yeyati, E. L., Panizza U, and Stein, E (2007). The cyclical nature of North-South FDI flows. Journal of International Money and Finance, 26, 104-130.

Yogo, U. T., and Ngo, M.M. (2018). Political competition and tax revenues in developing countries. Journal of International Development, 30, 302-322. 


\section{FIGURES}

Figure 1: Export product concentration and Non-resource tax revenue_Over the full sample

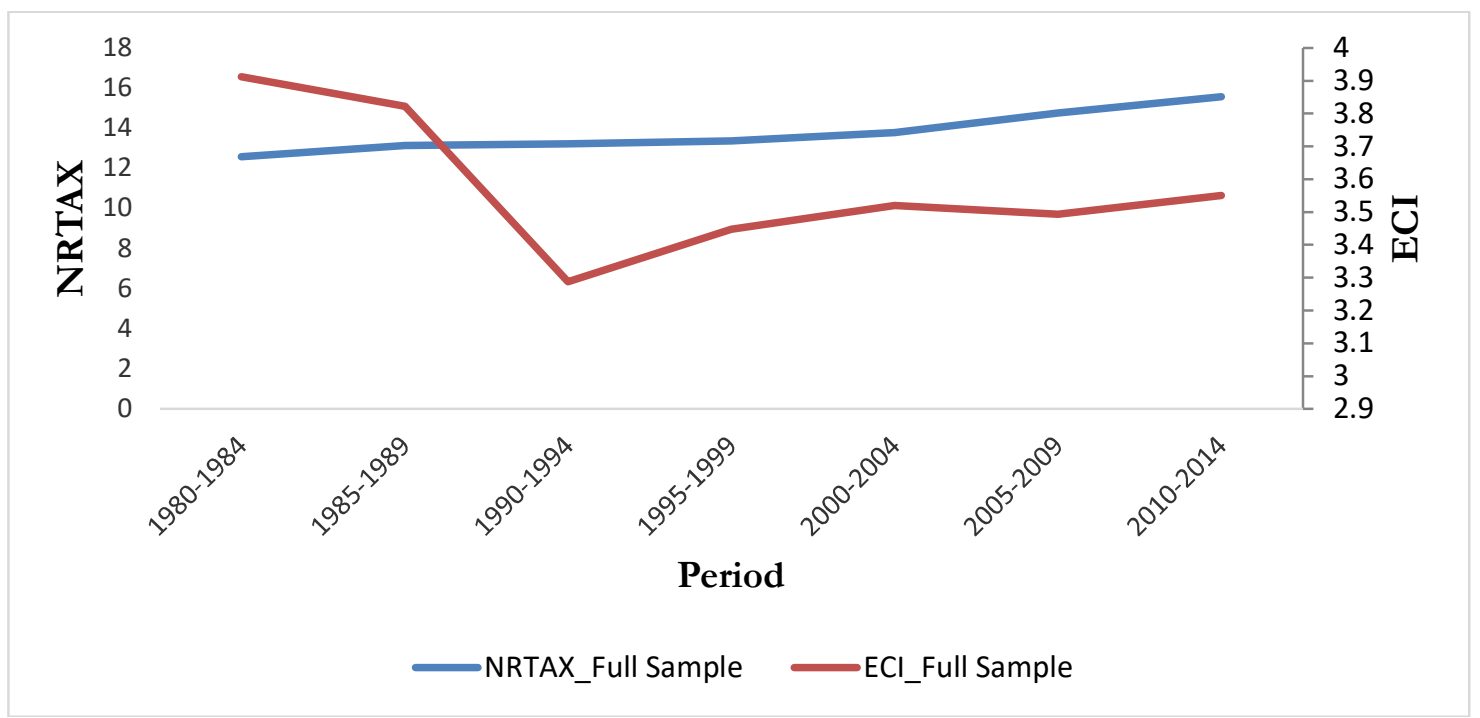

Source: Author

Figure 2: Poverty and Non-resource tax revenue_Over the full sample

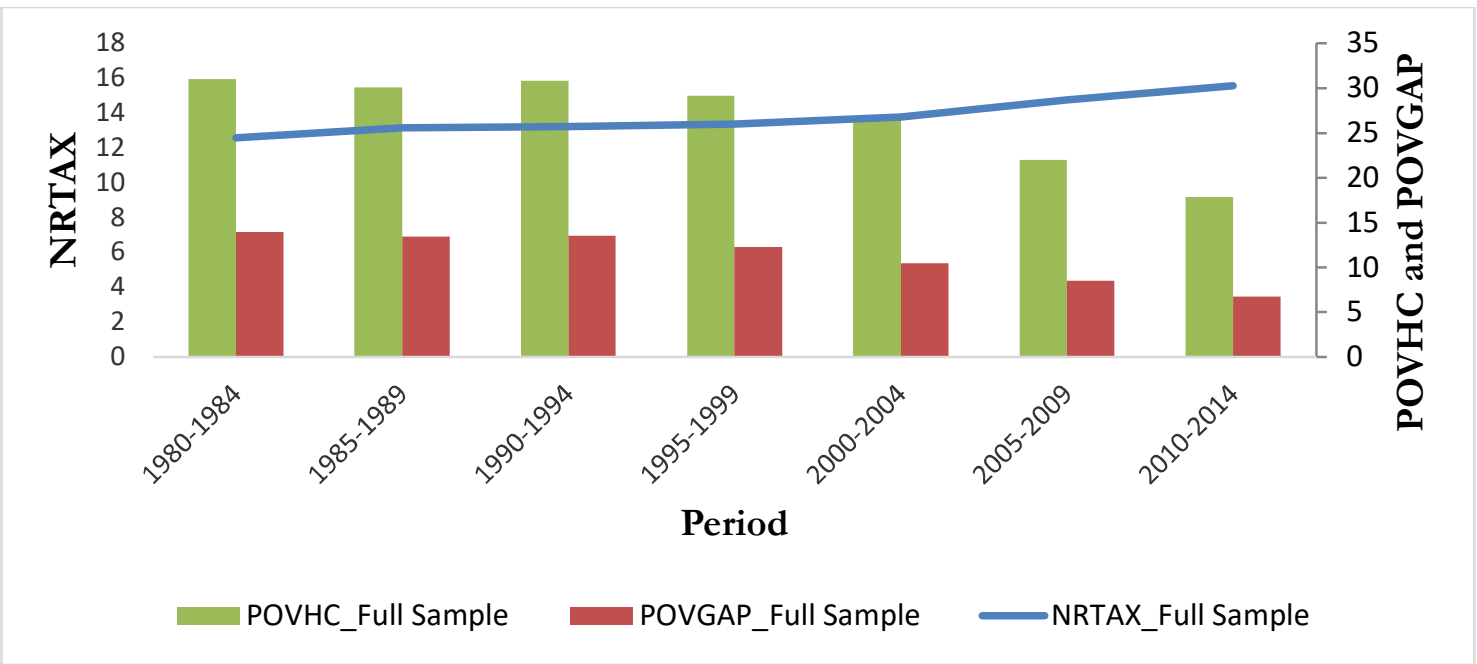

Source: Author 
Figure 3: Correlation pattern between export product concentration, poverty and non-resource tax revenue _over the full sample
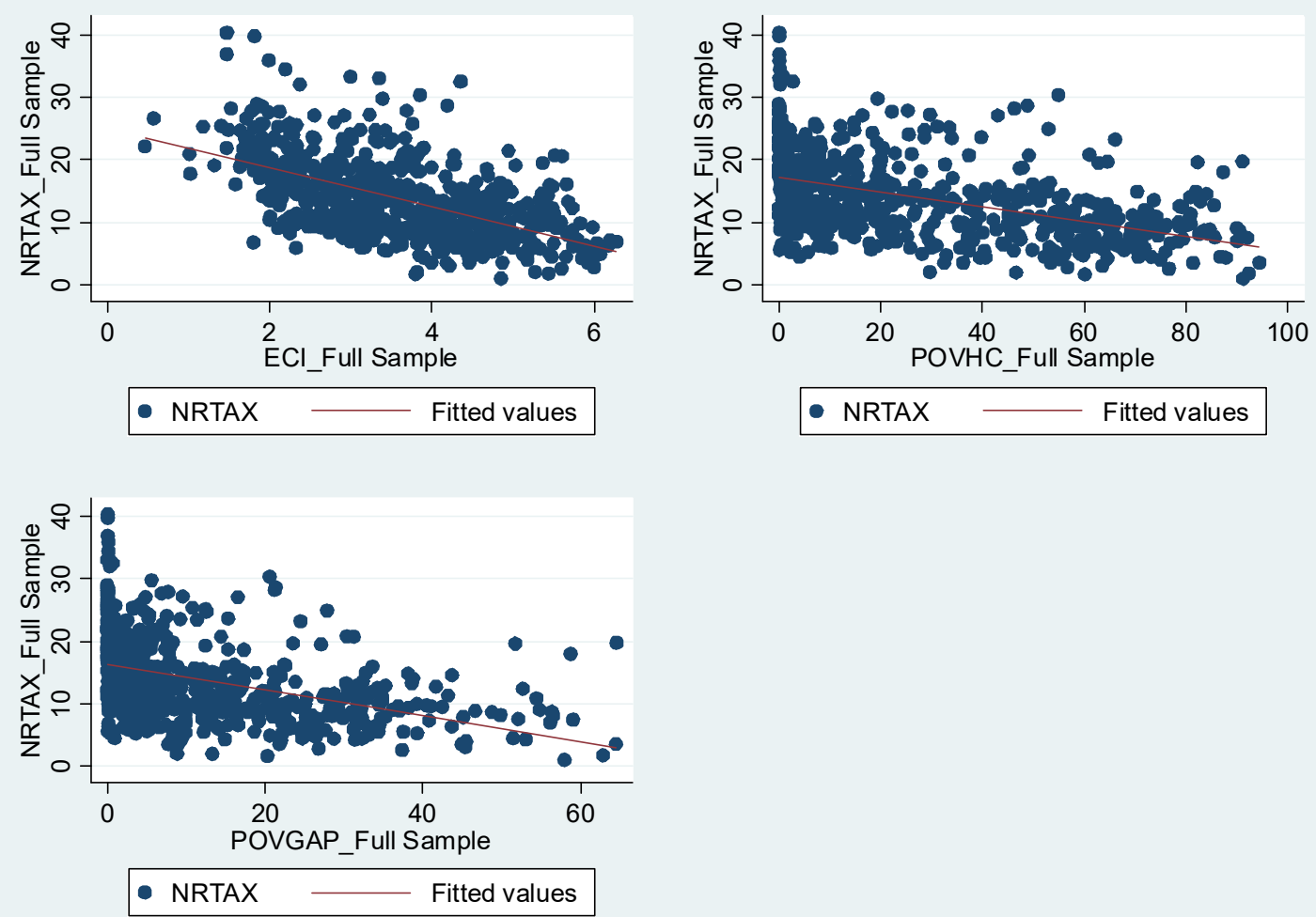

Source: Author 


\section{TABLES and APPENDICES}

Table 1: Effect of export product concentration and poverty and non-resource tax revenue Estimators: FE and FGLS

\begin{tabular}{|c|c|c|c|c|}
\hline & \multicolumn{2}{|c|}{ FE } & \multicolumn{2}{|c|}{ FGLS with panel-specific AR(1) } \\
\hline \multirow[t]{2}{*}{ Variables } & NRTAX & NRTAX & NRTAX & NRTAX \\
\hline & $(1)$ & $(2)$ & (3) & (4) \\
\hline \multirow[t]{2}{*}{ ECI } & -0.151 & -0.133 & $-1.843 * * *$ & $-1.881 * * *$ \\
\hline & $(0.182)$ & $(0.183)$ & $(0.103)$ & $(0.0986)$ \\
\hline \multirow[t]{2}{*}{ POVHC } & $-0.0534 * * *$ & & $-0.0335 * * *$ & \\
\hline & $(0.00972)$ & & $(0.00636)$ & \\
\hline \multirow[t]{2}{*}{ POVGAP } & & $-0.0853 * * *$ & & $-0.0606^{* * *}$ \\
\hline & & $(0.00928)$ & & $(0.00945)$ \\
\hline \multirow[t]{2}{*}{$\log ($ GDPC) } & 0.0474 & 0.355 & $0.403^{* *}$ & $0.442^{* * *}$ \\
\hline & $(0.403)$ & $(0.586)$ & $(0.174)$ & $(0.157)$ \\
\hline \multirow[t]{2}{*}{ OPEN } & $0.0184 * * *$ & $0.0182^{* * *}$ & $0.0304 * * *$ & $0.0303 * * *$ \\
\hline & $(0.00428)$ & $(0.00465)$ & $(0.00240)$ & $(0.00262)$ \\
\hline \multirow[t]{2}{*}{ INFL } & $-0.527 * * *$ & $-0.499 * * *$ & $-0.384 * * *$ & $-0.367 * * *$ \\
\hline & $(0.153)$ & $(0.147)$ & $(0.0685)$ & $(0.0676)$ \\
\hline \multirow[t]{2}{*}{ TERMS } & $0.00550^{* * *}$ & $0.00620^{* * *}$ & 0.00303 & 0.00322 \\
\hline & $(0.00139)$ & $(0.00149)$ & $(0.00215)$ & $(0.00210)$ \\
\hline \multirow[t]{2}{*}{ SHAGRI } & $-0.0642^{* * *}$ & $-0.0693^{* * *}$ & $-0.0700 * * *$ & $-0.0737 * * *$ \\
\hline & $(0.0179)$ & $(0.0183)$ & $(0.0101)$ & $(0.00966)$ \\
\hline \multirow[t]{2}{*}{ INST } & -0.0127 & -0.0168 & $-0.0545^{* * *}$ & $-0.0532^{* * *}$ \\
\hline & $(0.00909)$ & $(0.0115)$ & $(0.0203)$ & $(0.0198)$ \\
\hline \multirow[t]{2}{*}{$\log ($ POP $)$} & 0.323 & 0.233 & $-0.466^{* * *}$ & $-0.509 * * *$ \\
\hline & $(0.393)$ & $(0.359)$ & $(0.0753)$ & $(0.0685)$ \\
\hline \multirow[t]{2}{*}{ Constant } & 10.27 & 8.810 & $25.27 * * *$ & $25.54 * * *$ \\
\hline & $(7.450)$ & $(7.485)$ & $(2.107)$ & $(1.885)$ \\
\hline Observations - Countries & $525-111$ & $525-111$ & $520-106$ & $520-106$ \\
\hline Within R-squared & 0.2314 & 0.2363 & & \\
\hline Pseudo R-squared & & & 0.6757 & 0.6796 \\
\hline
\end{tabular}

Note: ${ }^{*}$-value $<0: 1 ;{ }^{*}$ p-value $<0: 05 ;{ }^{* *}$ p-value $<0: 01$. Robust Standard errors are in parenthesis. The Pseudo R2 has been computed for the regression based on the FGLS estimator as the correlation coefficient between the dependent variable and its predicted values. 
Table 2: Effect of export product concentration and poverty on non-resource tax revenue Estimator: Two-Step System GMM

\begin{tabular}{|c|c|c|c|c|}
\hline Variables & NRTAX & NRTAX & NRTAX & NRTAX \\
\hline & (1) & (2) & (3) & (4) \\
\hline \multirow{2}{*}{ NRTAX $_{\mathrm{t}-1}$} & $0.565^{* * *}$ & $0.593^{* * *}$ & $0.590^{* * *}$ & $0.649 * * *$ \\
\hline & $(0.0398)$ & $(0.0355)$ & $(0.0354)$ & $(0.0398)$ \\
\hline \multirow[t]{2}{*}{ ECI } & $-0.876^{* * *}$ & $-0.815^{* * *}$ & & \\
\hline & $(0.189)$ & $(0.159)$ & & \\
\hline \multirow[t]{2}{*}{ POVHC } & $-0.0760 * * *$ & & $-0.0778^{* * *}$ & $-0.0569 * * *$ \\
\hline & $(0.0135)$ & & $(0.0139)$ & $(0.0105)$ \\
\hline \multirow[t]{2}{*}{ POVGAP } & & $-0.102 * * *$ & & \\
\hline & & $(0.0222)$ & & \\
\hline \multirow[t]{2}{*}{ ECIINT } & & & $-0.953^{* * *}$ & \\
\hline & & & $(0.182)$ & \\
\hline \multirow[t]{2}{*}{ ECIEXT } & & & & $0.886^{* * *}$ \\
\hline & & & & $(0.333)$ \\
\hline \multirow[t]{2}{*}{ Log(GDPC) } & $-1.289 * * *$ & $-0.603^{* *}$ & $-1.222^{* * *}$ & -0.161 \\
\hline & $(0.285)$ & $(0.241)$ & $(0.321)$ & $(0.295)$ \\
\hline \multirow[t]{2}{*}{ OPEN } & 0.00599 & $0.00790^{*}$ & 0.00303 & 0.00527 \\
\hline & $(0.00506)$ & $(0.00455)$ & $(0.00484)$ & $(0.00513)$ \\
\hline \multirow[t]{2}{*}{ INFL } & $-0.281 * * *$ & $-0.208^{* *}$ & $-0.294 * * *$ & $-0.202^{* *}$ \\
\hline & $(0.0861)$ & $(0.0870)$ & $(0.0899)$ & $(0.0835)$ \\
\hline \multirow[t]{2}{*}{ TERMS } & $0.00559 * * *$ & $0.00677^{* * *}$ & $0.00500^{* *}$ & 0.00193 \\
\hline & $(0.00199)$ & $(0.00199)$ & $(0.00200)$ & $(0.00176)$ \\
\hline \multirow[t]{2}{*}{ SHAGRI } & -0.0344 & -0.0202 & -0.0282 & -0.0240 \\
\hline & $(0.0212)$ & $(0.0193)$ & $(0.0242)$ & $(0.0214)$ \\
\hline \multirow[t]{2}{*}{$\log (\mathrm{POP})$} & $-0.449 * * *$ & $-0.374^{* *}$ & -0.238 & 0.120 \\
\hline & $(0.165)$ & $(0.155)$ & $(0.152)$ & $(0.163)$ \\
\hline \multirow[t]{2}{*}{ INST } & 0.0471 & $0.0596^{* *}$ & $0.0482^{*}$ & $0.0883^{* * *} *$ \\
\hline & $(0.0317)$ & $(0.0283)$ & $(0.0271)$ & $(0.0254)$ \\
\hline
\end{tabular}




\begin{tabular}{|c|c|c|c|c|}
\hline Observations - Countries & $463-111$ & $463-111$ & $463-111$ & $463-111$ \\
\hline Number of Instruments & 63 & 63 & 63 & 63 \\
\hline AR1 (P-Value) & 0.0278 & 0.0282 & 0.0221 & 0.0146 \\
\hline AR2 (P-Value) & 0.2524 & 0.2077 & 0.2640 & 0.2307 \\
\hline AR3 (P-Value) & 0.2304 & 0.2677 & 0.2446 & 0.2976 \\
\hline OID (P-Value) & 0.2894 & 0.1953 & 0.3845 & 0.1242 \\
\hline
\end{tabular}

Note: ${ }^{*} p$-value $<0.1 ;{ }^{*} p$-value $<0.05 ;{ }^{* * *} p$-value $<0.01$. Robust Standard Errors are in parenthesis. In the two-step system GMM estimations, the variables "ECI", "ECIINT", "ECIEXT", "POVHC", "POVGAP", "INST", "OPEN" bave been considered as endogenous. Time dummies have been included in the regressions, but were not significant. The latter have used 3 lags of the dependent variable as instruments, and 2 lags of endogenous variables as instruments. 
Table 3: Effect of export product concentration and poverty on non-resource tax revenue for varying values of real per capita income

Estimator: Two-Step System GMM

\begin{tabular}{|c|c|c|c|c|}
\hline Variables & NRTAX & NRTAX & NRTAX & NRTAX \\
\hline & (1) & (2) & (3) & (4) \\
\hline \multirow[t]{2}{*}{ NRTAX $_{\mathrm{t}-1}$} & $0.614 * * *$ & $0.623 * * *$ & $0.625^{* * *}$ & $0.644 * * *$ \\
\hline & $(0.0395)$ & $(0.0320)$ & $(0.0383)$ & $(0.0394)$ \\
\hline \multirow[t]{2}{*}{ ECI } & $8.846^{* * *}$ & $7.879 * * *$ & & \\
\hline & $(1.532)$ & (1.431) & & \\
\hline \multirow[t]{2}{*}{ POVHC } & $-0.311 * * *$ & & $-0.105^{* * *}$ & $-0.0579 * * *$ \\
\hline & $(0.0773)$ & & $(0.0145)$ & $(0.0102)$ \\
\hline \multirow[t]{2}{*}{ POVGAP } & & $-0.494 * * *$ & & \\
\hline & & $(0.149)$ & & \\
\hline \multirow[t]{2}{*}{ ECI*Log(GDPC) } & $-1.206^{* * *}$ & $-1.076^{* * *}$ & & \\
\hline & $(0.200)$ & $(0.188)$ & & \\
\hline \multirow[t]{2}{*}{ POVHC*Log(GDPC) } & $0.0351 * * *$ & & & \\
\hline & $(0.0117)$ & & & \\
\hline \multirow[t]{2}{*}{ POVGAP*Log(GDPC) } & & $0.0631 * * *$ & & \\
\hline & & $(0.0231)$ & & \\
\hline \multirow[t]{2}{*}{ ECIINT } & & & $4.154 * *$ & \\
\hline & & & $(1.744)$ & \\
\hline \multirow[t]{2}{*}{ ECIINT*Log(GDPC) } & & & $-0.606 * * *$ & \\
\hline & & & $(0.223)$ & \\
\hline \multirow[t]{2}{*}{ ECIEXT } & & & & $9.440^{* * *}$ \\
\hline & & & & $(1.787)$ \\
\hline \multirow[t]{2}{*}{ ECIEXT*Log(GDPC) } & & & & $-1.302 * * *$ \\
\hline & & & & $(0.264)$ \\
\hline \multirow[t]{2}{*}{$\log (G D P C)$} & $2.401 * * *$ & $2.771 * * *$ & 0.235 & 0.294 \\
\hline & $(0.691)$ & $(0.701)$ & $(0.655)$ & $(0.343)$ \\
\hline \multirow[t]{2}{*}{ OPEN } & -0.00657 & -0.00313 & -0.00239 & -0.00155 \\
\hline & $(0.00501)$ & $(0.00485)$ & $(0.00537)$ & $(0.00531)$ \\
\hline \multirow[t]{2}{*}{ INFL } & $-0.177 * *$ & -0.126 & $-0.236 * * *$ & $-0.152^{*}$ \\
\hline & $(0.0890)$ & $(0.0857)$ & $(0.0894)$ & $(0.0815)$ \\
\hline \multirow[t]{2}{*}{ TERMS } & $0.00776^{* * *}$ & $0.00951^{* * * *}$ & $0.00390^{*}$ & 0.000789 \\
\hline & $(0.00232)$ & $(0.00197)$ & $(0.00210)$ & $(0.00160)$ \\
\hline \multirow[t]{2}{*}{ SHAGRI } & $-0.0391 *$ & $-0.0491 * *$ & -0.0188 & -0.0315 \\
\hline & $(0.0236)$ & $(0.0220)$ & $(0.0234)$ & $(0.0203)$ \\
\hline \multirow[t]{2}{*}{ INST } & $0.0526^{*}$ & $0.0541 *$ & 0.0235 & $0.0715^{* * *}$ \\
\hline & $(0.0294)$ & $(0.0285)$ & $(0.0284)$ & $(0.0276)$ \\
\hline \multirow[t]{2}{*}{$\log ($ POP $)$} & -0.00249 & -0.000711 & -0.139 & 0.241 \\
\hline & $(0.179)$ & $(0.158)$ & $(0.169)$ & $(0.160)$ \\
\hline Observations - Countries & $463-111$ & $463-111$ & $463-111$ & $463-111$ \\
\hline Number of Instruments & 65 & 65 & 64 & 64 \\
\hline AR1 (P-Value) & 0.0263 & 0.0325 & 0.0213 & 0.0134 \\
\hline AR2 (P-Value) & 0.1154 & 0.1075 & 0.1620 & 0.3275 \\
\hline AR3 (P-Value) & 0.3474 & 0.4215 & 0.2450 & 0.2917 \\
\hline
\end{tabular}


OID (P-Value)

0.3518

0.2439

0.2340

0.2452

Note: ${ }^{*}$-value $<0.1 ;{ }^{* *}$-value $<0.05 ;{ }^{* * *}$-value $<0.01$. Robust Standard Errors are in parenthesis. In the twostep system GMM estimations, the variables "ECI", "ECIINT", "ECIEXT", "POVHC", "POVGAP", "INST", "OPEN" have been considered as endogenous. Time dummies have been included in the regressions, but were not significant. The regressions have used 3 lags of the dependent variable as instruments, and 2 lags of endogenous variables as instruments. 
Table 4: Interaction effect between export product concentration and poverty on non-resource tax revenue Estimator: Two-Step System GMM

\begin{tabular}{|c|c|c|c|c|c|c|}
\hline Variables & NRTAX & NRTAX & NRTAX & NRTAX & NRTAX & NRTAX \\
\hline & (1) & (2) & (3) & (4) & (5) & (6) \\
\hline NRTAX $_{\mathrm{t}-1}$ & $(0.0259)$ & $(0.0263)$ & $(0.0282)$ & $(0.0258)$ & $(0.0318)$ & $(0.0299)$ \\
\hline ECI*POVHC & $(0.00497)$ & & & & & \\
\hline \multirow[t]{2}{*}{ ECI*POVGAP } & & $0.0523 * * *$ & & & & \\
\hline & & $(0.00830)$ & & & & \\
\hline \multirow[t]{2}{*}{ ECIINT*POVGAP } & & & & $0.0153^{*}$ & & \\
\hline & & & & $(0.00848)$ & & \\
\hline \multirow[t]{2}{*}{ ECIEXT*POVHC } & & & & & $0.0504 * * *$ & \\
\hline & & & & & $(0.00807)$ & \\
\hline \multirow[t]{2}{*}{ ECIEXT*POVGAP } & & & & & & $0.0781^{* * *}$ \\
\hline & & & & & & $(0.0122)$ \\
\hline ECIEXT & & & & & $(0.526)$ & $(0.459)$ \\
\hline \multirow[t]{2}{*}{ POVHC } & $-0.176^{* * *}$ & & $-0.0970^{* * *}$ & & $-0.0804^{* * *}$ & \\
\hline & $(0.0233)$ & & $(0.0225)$ & & $(0.00777)$ & \\
\hline \multirow[t]{2}{*}{ POVGAP } & & $-0.312 * * *$ & & $-0.118^{* * *}$ & & $-0.141 * * *$ \\
\hline & & $(0.0378)$ & & $(0.0336)$ & & $(0.0144)$ \\
\hline \multirow{2}{*}{ Log(GDPC) } & $-1.465^{* * *}$ & $-0.963 * * *$ & $-1.448^{* * *}$ & $-0.585^{* * *}$ & -0.429 & -0.0672 \\
\hline & $(0.223)$ & $(0.182)$ & $(0.282)$ & $(0.210)$ & $(0.263)$ & $(0.174)$ \\
\hline OPEN & 0.000678 & 0.00491 & 0.00467 & 0.00432 & 0.00297 & 0.00553 \\
\hline
\end{tabular}




\begin{tabular}{|c|c|c|c|c|c|c|}
\hline & $(0.00402)$ & $(0.00411)$ & $(0.00362)$ & $(0.00329)$ & $(0.00473)$ & $(0.00456)$ \\
\hline INFL & $-0.278 * * *$ & $-0.294 * * *$ & $-0.347 * * *$ & $-0.316^{* * *}$ & $-0.216^{* * *}$ & $-0.193 * *$ \\
\hline TERMS & $0.00634 * * *$ & $0.00817 * * *$ & $0.00801^{* * *}$ & $0.00987 * * *$ & $0.00440 * * *$ & $0.00485^{* * *}$ \\
\hline \multirow[t]{2}{*}{ SHAGRI } & $-0.0474 * * *$ & $-0.0547 * * *$ & $-0.0366^{* *}$ & $-0.0281 *$ & $-0.0321 *$ & $-0.0313^{*}$ \\
\hline & $(0.0169)$ & $(0.0139)$ & $(0.0162)$ & $(0.0158)$ & $(0.0186)$ & $(0.0176)$ \\
\hline INST & 0.0182 & 0.00384 & $0.0646^{* * *}$ & $0.0941 * * *$ & $0.0718^{* * *}$ & $0.0587 * * *$ \\
\hline $\log ($ POP $)$ & $(0.111)$ & $(0.106)$ & $(0.107)$ & $(0.0929)$ & $(0.116)$ & $(0.113)$ \\
\hline $\begin{array}{l}\text { Threshold of "POVHC" } \\
\text { or "POVGAP" }\end{array}$ & $\begin{array}{c}55.22(= \\
1.447 / 0.0262)\end{array}$ & $\begin{array}{c}27.07 \\
(=1.416 / 0.0523)\end{array}$ & n.a. & n.a. & $\begin{array}{c}29.6 \\
(=1.494 / 0.0504)\end{array}$ & $\begin{array}{c}13.2 \\
(=1.030 / 0.0781)\end{array}$ \\
\hline Observations - Countries & $463-111$ & $463-111$ & $463-111$ & $463-111$ & $463-111$ & $463-111$ \\
\hline Number of Instruments & 73 & 73 & 73 & 73 & 73 & 73 \\
\hline
\end{tabular}

Note: * ${ }^{*}$-value $<0.1 ; * *$-value $<0.05$; ***p-value $<0.01$. Robust Standard Errors are in parenthesis. In the two-step system GMM estimations, the variables "ECI", "ECIINT", "ECIEXT", "POVHC", "POVGAP", "INST", "OPEN" have been considered as endogenous. Time dummies have been included in the regressions, but were not significant. The regressions have used 3 lags of the dependent variable as instruments, and 2 lags of endogenous variables as instruments. 
Table 5: Channels through which export product concentration and poverty influence nonresource tax revenue performance

Estimator: Two-Step System GMM

\begin{tabular}{|c|c|c|c|c|}
\hline Variables & NRTAX & NRTAX & NRTAX & NRTAX \\
\hline & (1) & (2) & (3) & (4) \\
\hline \multirow[t]{2}{*}{ NRTAX $_{\mathrm{t}-1}$} & $0.633 * * *$ & $0.629 * * *$ & $0.671 * * *$ & $0.689 * * *$ \\
\hline & $(0.0348)$ & $(0.0268)$ & $(0.0274)$ & $(0.0229)$ \\
\hline \multirow[t]{2}{*}{ ECI*GRVOL } & $-0.157 * * *$ & & & \\
\hline & $(0.0262)$ & & & \\
\hline \multirow[t]{2}{*}{ ECI*GROWTH } & & 0.0348 & & \\
\hline & & $(0.0346)$ & & \\
\hline \multirow[t]{2}{*}{ POVHC*GRVOL } & & & $-0.00996 * * *$ & \\
\hline & & & $(0.00119)$ & \\
\hline \multirow[t]{2}{*}{ POVGAP*GRVOL } & & & & $-0.0238^{* * *}$ \\
\hline & & & & $(0.00234)$ \\
\hline \multirow[t]{2}{*}{ ECI } & 0.251 & $-1.151 * * *$ & $-0.525^{* * *}$ & $-0.497 * * *$ \\
\hline & $(0.206)$ & $(0.210)$ & $(0.184)$ & $(0.153)$ \\
\hline \multirow[t]{2}{*}{ POVHC } & $-0.0968^{* * *}$ & $-0.0564 * * *$ & $-0.0355^{* * *}$ & \\
\hline & $(0.0122)$ & $(0.00904)$ & $(0.0119)$ & \\
\hline \multirow[t]{2}{*}{ POVGAP } & & & & 0.00159 \\
\hline & & & & $(0.0167)$ \\
\hline \multirow[t]{2}{*}{ GRVOL } & $0.669 * * *$ & & $0.409 * * *$ & $0.389 * * *$ \\
\hline & $(0.111)$ & & $(0.0478)$ & $(0.0449)$ \\
\hline \multirow[t]{2}{*}{ GROWTH } & & -0.0232 & & \\
\hline & & $(0.151)$ & & \\
\hline \multirow[t]{2}{*}{$\log ($ GDPC $)$} & $-1.833 * * *$ & $-1.112^{* * *}$ & $-1.861 * * *$ & $-1.222^{* * *}$ \\
\hline & $(0.287)$ & $(0.198)$ & $(0.274)$ & $(0.200)$ \\
\hline \multirow[t]{2}{*}{ OPEN } & 0.00326 & 0.00533 & $0.00856^{*}$ & $0.0110^{* *}$ \\
\hline & $(0.00505)$ & $(0.00342)$ & $(0.00492)$ & $(0.00436)$ \\
\hline \multirow[t]{2}{*}{ INFL } & $-0.217 * * *$ & $-0.199 * * *$ & $-0.176^{* *}$ & -0.105 \\
\hline & $(0.0829)$ & $(0.0634)$ & $(0.0797)$ & $(0.0819)$ \\
\hline \multirow[t]{2}{*}{ TERMS } & $0.00292^{*}$ & $0.00778^{* * *}$ & $0.00767 * * *$ & $0.00798^{* * *}$ \\
\hline & $(0.00176)$ & $(0.00173)$ & $(0.00173)$ & $(0.00156)$ \\
\hline \multirow[t]{2}{*}{ SHAGRI } & $-0.0434 * *$ & $-0.0220^{* *}$ & $-0.0535 * * *$ & $-0.0474 * * *$ \\
\hline & $(0.0188)$ & $(0.0110)$ & $(0.0155)$ & $(0.0148)$ \\
\hline \multirow[t]{2}{*}{ INST } & $0.0569 * *$ & $0.0467 * *$ & $0.0509^{* *}$ & $0.0643^{* * *}$ \\
\hline & $(0.0252)$ & $(0.0225)$ & $(0.0203)$ & $(0.0173)$ \\
\hline \multirow[t]{2}{*}{$\log ($ POP $)$} & $-0.307 * *$ & -0.120 & -0.0800 & -0.0132 \\
\hline & $(0.126)$ & $(0.0846)$ & $(0.124)$ & $(0.101)$ \\
\hline Observations - Countries & $462-110$ & $463-111$ & $462-110$ & $462-110$ \\
\hline Number of Instruments & 74 & 83 & 74 & 74 \\
\hline AR1 (P-Value) & 0.0246 & 0.0265 & 0.0194 & 0.0210 \\
\hline AR2 (P-Value) & 0.2877 & 0.1959 & 0.2259 & 0.1787 \\
\hline AR3 (P-Value) & 0.2342 & 0.2450 & 0.2548 & 0.2702 \\
\hline OID (P-Value) & 0.3513 & 0.2628 & 0.4199 & 0.6028 \\
\hline
\end{tabular}

Note: ${ }^{*}$-value $<0.1$; ${ }^{* *}$-value $<0.05$; ***-value $<0.01$. Robust Standard Errors are in parenthesis. In the twostep system GMM estimations, the variables "ECI", "GRVOL", "GROWTH", "POVHC", "POVGAP", 
"INST", "OPEN" have been considered as endogenous. Time dummies have been included in the regressions, but were not significant. The regressions have used 3 lags of the dependent variable as instruments, and 2 lags of endogenous variables as instruments. 
Appendix 1: Definition and Source of variables

\begin{tabular}{|c|c|c|}
\hline Variables & Definition & Sources \\
\hline NRTAX & $\begin{array}{l}\text { This is the share of a country's total non-resource tax revenue in } \\
\text { percentage of GDP. It represents the difference between the } \\
\text { total tax revenue excluding grants and social contributions (in \% } \\
\text { GDP) and the resource tax revenue (in \% GDP), the latter } \\
\text { being the tax revenue collected on natural resources. }\end{array}$ & $\begin{array}{l}\text { UNU-WIDER Public Revenue Dataset. See online: } \\
\text { https://www.wider.unu.edu/project/government-revenue-dataset }\end{array}$ \\
\hline ECI & $\begin{array}{l}\text { This is the variable capturing the overall export product } \\
\text { concentration. It is calculated using the Theil Index and } \\
\text { following the definitions and methods used in Cadot et al. } \\
\text { (2011). The overall Theil index of export product concentration } \\
\text { is the sum of the intensive and extensive components of the } \\
\text { "ECI" variable. Indeed, export product diversification can occur } \\
\text { either over product narrowly defined or trading partners. It can } \\
\text { be broken down into the extensive and intensive margins of } \\
\text { concentration. In fact, extensive export diversification reflects } \\
\text { an increase in the number of export products or trading } \\
\text { partners, while intensive export diversification considers the } \\
\text { shares of export volumes across active products or trading } \\
\text { partners. This index has been computed using a classification of } \\
\text { products into "Traditional", "New", or "Non-Traded" products } \\
\text { categories. A rise in the values of "ECI" signifies an increase in } \\
\text { the level of overall export product concentration, while a } \\
\text { decrease in the values of this index reflects a rise in the degree } \\
\text { of overall export product concentration (that is, greater export } \\
\text { product diversification). }\end{array}$ & $\begin{array}{l}\text { Details on the calculation of this Index could be found online: } \\
\text { International Monetary Fund's Diversification Toolkit - See data } \\
\text { online at: https://data.imf.org/?sk=3567E911-4282-4427-98F9- } \\
\text { 2B8A6F83C3B6 }\end{array}$ \\
\hline ECIINT & $\begin{array}{l}\text { This the index of export product concentration at the intensive } \\
\text { margins. Higher values of this index indicate a rise in the level } \\
\text { of export product concentration at the intensive margins, while } \\
\text { declining values of this index reflect lower levels of } \\
\text { concentration at the intensive margins, i.e., greater } \\
\text { diversification of export product at the intensive margins. }\end{array}$ & $\begin{array}{l}\text { Details on the calculation of this Index could be found online: } \\
\text { International Monetary Fund's Diversification Toolkit - See data } \\
\text { online at: https://data.imf.org/?sk=3567E911-4282-4427-98F9- } \\
\text { 2B8A6F83C3B6 }\end{array}$ \\
\hline
\end{tabular}




\begin{tabular}{|c|c|c|}
\hline ECIEXT & $\begin{array}{l}\text { This the index of export product concentration at the extensive } \\
\text { margins. Higher values of this index indicate greater export } \\
\text { product concentration at the extensive margins, while declining } \\
\text { values of this index reflect a lower concentration at the } \\
\text { extensive margins, i.e., greater diversification of export product } \\
\text { at the extensive margins. }\end{array}$ & $\begin{array}{l}\text { Details on the calculation of this Index could be found online: } \\
\text { International Monetary Fund's Diversification Toolkit - See data } \\
\text { online at: https://data.imf.org/?sk=3567E911-4282-4427-98F9- } \\
\text { 2B8A6F83C3B6 }\end{array}$ \\
\hline POVHC & $\begin{array}{l}\text { This is the indicator of poverty headcount ratio at } \$ 1.90 \text { a day. It } \\
\text { represents the percentage of the population living on less than } \\
\qquad \$ 1.90 \text { a day at } 2011 \text { international prices. }\end{array}$ & $\begin{array}{c}\text { Data on this indicator is collected from the Word Development } \\
\text { Indicators (WDI) of the World Bank and POVCALNET of the } \\
\text { World Bank (see } \\
\text { http://iresearch.worldbank.org/PovcalNet/povOnDemand.aspx). } \\
\text { Missing data has been completed using linear interpolation technique } \\
\text { over } 2 \text { to } 4 \text { years (see also Santos-Paulino, 2017). }\end{array}$ \\
\hline POVGAP & $\begin{array}{l}\text { This is the indicator of poverty gap at } \$ 1.90 \text { a day (2011 PPP). It } \\
\text { is the mean shortfall in income or consumption from the } \\
\text { poverty line } \$ 1.90 \text { a day (counting the nonpoor as having zero } \\
\text { shortfall), expressed as a percentage of the poverty line. This } \\
\text { measure reflects the depth of poverty as well as its incidence. }\end{array}$ & $\begin{array}{c}\text { Data on this indicator is collected from the WDI and POVCALNET } \\
\text { of the World Bank (see } \\
\text { http://iresearch.worldbank.org/PovcalNet/povOnDemand.aspx). } \\
\begin{array}{c}\text { Missing data has been completed using linear interpolation technique } \\
\text { over } 2 \text { to } 4 \text { years (see also Santos-Paulino, 2017). }\end{array}\end{array}$ \\
\hline GDPC & GDP per capita (constant 2010 US\$) & WDI \\
\hline SHAGRI & $\begin{array}{l}\text { Share of value added in the agriculture sector in percentage of } \\
\text { total output value. }\end{array}$ & WDI \\
\hline INFL & $\begin{array}{l}\text { The variable "INFL" has been calculated using the following } \\
\text { formula (e.g., Yeyati et al. 2007): INFL = } \\
\text { sign (INFLATION) * log }(1+|I N F L A T I O N|)(2) \text {, where } \\
|I N F L A T I O N| \text { refers to the absolute value of the annual } \\
\text { inflation rate }(\%) \text {, denoted "INFLATION". } \\
\text { The annual inflation rate }(\%) \text { is based on consumer price index - } \\
\text { CPI- (annual \%) where missing values have been replaced with } \\
\text { values of the GDP Deflator (annual \%). }\end{array}$ & Authors' calculation based on data from the WDI. \\
\hline POP & Total Population & WDI \\
\hline OPEN & $\begin{array}{l}\text { This is the indicator of trade openness. It is measured by the } \\
\text { share of sum of exports and imports of goods and services in } \\
\text { GDP. }\end{array}$ & WDI \\
\hline
\end{tabular}




\begin{tabular}{|c|c|c|}
\hline GRVOL & $\begin{array}{c}\text { This is the measure of the economic growth volatility. It has } \\
\text { been calculated as the standard deviation of the annual } \\
\text { economic growth rate (growth rate of real GDP) over non- } \\
\text { overlapping sub-periods of 5-year. }\end{array}$ & Author's calculation based on economic growth rate data extracted \\
from the WDI.
\end{tabular}


Appendix 2: Descriptive statistics on variables used in the model

\begin{tabular}{|c|c|c|c|c|c|}
\hline Variable & Observations & Mean & Standard deviation & Minimum & Maximum \\
\hline NRTAX & 463 & 13.612 & 5.545 & 1.022 & 33.037 \\
\hline ECI & 463 & 3.545 & 1.117 & 1.630 & 6.269 \\
\hline ECIINT & 463 & 3.090 & 0.979 & 1.451 & 5.869 \\
\hline ECIEXT & 463 & 0.455 & 0.549 & -0.036 & 2.707 \\
\hline POVHC & 463 & 26.392 & 25.986 & 0.000 & 94.402 \\
\hline POVGAP & 463 & 10.792 & 12.866 & 0.000 & 64.518 \\
\hline GRVOL & 462 & 3.051 & 2.606 & 0.244 & 22.239 \\
\hline GROWTH & 463 & 4.228 & 2.849 & -11.480 & 21.570 \\
\hline OPEN & 463 & 72.519 & 36.003 & 13.273 & 229.638 \\
\hline INFLATION & 463 & 30.280 & 308.385 & -5.903 & 6424.987 \\
\hline GDPC & 463 & 3753.109 & 4136.624 & 153.903 & 23720.730 \\
\hline TERMS & 463 & 116.381 & 39.365 & 36.751 & 482.975 \\
\hline SHAGRI & 463 & 18.103 & 12.603 & 1.855 & 63.732 \\
\hline POP & 463 & $5.17 \mathrm{e}+07$ & $1.77 \mathrm{e}+08$ & 87376.8 & $1.35 \mathrm{e}+09$ \\
\hline INST & 463 & 2.8 & 5.999 & -9 & 10 \\
\hline
\end{tabular}


Appendix 3: List of countries contained in the full sample

\begin{tabular}{|c|c|c|c|}
\hline \multicolumn{4}{|c|}{ Full sample } \\
\hline Albania & Czech Republic & Lithuania & Slovak Republic \\
\hline Algeria & Djibouti & Madagascar & Slovenia \\
\hline Angola & Dominican Republic & Malawi & South Africa \\
\hline Argentina & Ecuador & Malaysia & Sri Lanka \\
\hline Armenia & Egypt, Arab Rep. & Mauritania & Sudan \\
\hline Azerbaijan & El Salvador & Mauritius & Suriname \\
\hline Bangladesh & Estonia & Mexico & Tajikistan \\
\hline Belarus & Eswatini & Moldova & Tanzania \\
\hline Benin & Ethiopia & Mongolia & Thailand \\
\hline Bhutan & Gabon & Morocco & Togo \\
\hline Bolivia & Gambia, The & Mozambique & Tunisia \\
\hline Botswana & Georgia & Namibia & Turkey \\
\hline Brazil & Guatemala & Nepal & Turkmenistan \\
\hline Bulgaria & Guinea & Nicaragua & Uganda \\
\hline Burkina Faso & Guinea-Bissau & Niger & Ukraine \\
\hline Burundi & Guyana & Nigeria & Uruguay \\
\hline Cabo Verde & Haiti & North Macedonia & Uzbekistan \\
\hline Cambodia & Honduras & Pakistan & Venezuela, RB \\
\hline Cameroon & Hungary & Panama & Vietnam \\
\hline $\begin{array}{c}\text { Central African } \\
\text { Republic }\end{array}$ & India & Papua New Guinea & Zambia \\
\hline Chad & Indonesia & Paraguay & Zimbabwe \\
\hline Chile & Iran, Islamic Rep. & Peru & \\
\hline China & Jordan & Philippines & \\
\hline Colombia & Kazakhstan & Poland & \\
\hline Comoros & Kenya & Romania & \\
\hline Congo, Dem. Rep. & Kiribati & Russian Federation & \\
\hline Congo, Rep. & Kyrgyz Republic & Rwanda & \\
\hline Costa Rica & Lao PDR & Senegal & \\
\hline Cote d'Ivoire & Latvia & Serbia & \\
\hline Croatia & Liberia & Sierra Leone & \\
\hline
\end{tabular}

